\title{
FORTIFIED SETTLEMENTS OF DEMIDOVKA AND VYAZOVENKI IN THE SMOLENSK LAND: HIERARCHY, CHRONOLOGY AND CULTURAL ATTRIBUTION
}

\author{
(C) 2020 г. Nikolay A. Krenke ${ }^{1, *}$, Mikhail M. Kazansky ${ }^{2, * *}$, Nikolay V. Lopatin ${ }^{1, * * *}$, \\ Kirill A. Ganichev ${ }^{1, * * *}$, Ivan N. Ershov ${ }^{1, * * * *}$, Ekaterina G. Ershova ${ }^{3, * * * * * *}$ \\ Fyodor E. Modestov ${ }^{4, * * * * * *}$, Vera A. Raeva ${ }^{1, * * * * * * * *}$ \\ ${ }^{1}$ Institute of Archaeology RAS, Moscow, Russia \\ ${ }^{2}$ National Research Centre, France \\ ${ }^{3}$ Lomonosov Moscow State University, Russia \\ ${ }^{4}$ Smolensk Regional Centre for the Protection and Use of Historical and Cultural Heritage Sites, Smolensk, Russia
}

\author{
${ }^{*}$ E-mail:nkrenke@mail.ru \\ ${ }^{* *} E$-mail: michel.kazanski53@gmail.com \\ ${ }^{* * *} E$-mail: n.lopatin@gmail.com \\ ${ }^{* * * * *}$ E-mail: kirganichev@yandex.ru \\ ${ }^{* * * * * *}$ E-mail: ershovin@yandex.ru \\ ${ }^{* * * * * *}$ E-mail: ekaterinagershova@mail.ru \\ ${ }^{* * * * * * *} E$-mail: archsmolzop@yandex.ru \\ ${ }^{* * * * * * * * *}$ E-mail: veraraeva@mail.ru
}

Received on 21.02.2020 2.

\begin{abstract}
The article examines finds from two fortified settlements located near Smolensk. It provides new radiocarbon dates that prove the demise of the fortified settlement of Demidovka at the turn of the $5 / 6^{\text {th }}$ century AD. The analysis of the distribution of prestigious silver items and armament on the sites of the "Demidovka circle" and the presence of a large long house provide grounds for an assumption about the central position of this settlement in the Smolensk district and the presence of a "German component" in it. The data of spore-pollen analysis are used for the reconstruction of the landscape surrounding the fortified settlement. The authors suggest that in the late period when militarized "elite" resided in the settlement its vicinity was used for grazing. As a result of the study, a hypothesis is proposed that the fortified settlements of Demidovka (the $3^{\text {rd }}-5^{\text {th }}$ centuries) and Vyazovenki (the $6^{\text {th }}-7^{\text {th }}$ centuries) were centers of power in the Smolensk land during the two periods of time preceding the transition of this function to Smolensk (Cathedral Hill) and Gnezdovo.
\end{abstract}

Keywords: the fortified settlement of Demidovka, buckles, Germans, Slavs, the Kolochin culture, spore-pollen analysis, silver jewelry.

This article is a translation of: Krenke N.A., Kazansky M.M., Lopatin N.V., Ganichev K.A., Ershov I.N., Ershova E.G., Modestov F.E., Raeva V.A. 2021. The fortified settlements of Demidovka and Vyazovenki in Smolensk land: hierarchy, chronology and cultural attribution. Rossiiskaia arkheologiia, 1, pp. 102-121. DOI: 10.31857/S086960630013711-1.

DOI: $10.31857 / \mathrm{S} 086960630014370-6$

In 2017-2019, the authors of this article began new studies of the fortified settlements of Demidovka and Vyazovenki, located in the vicinity of Smolensk. Both sites (more precisely, their upper horizons) are attributed to the Tushemlin archaeological culture by the classic of Smolensk archeology prof. Schmidt. Taking into account the continuing controversial nature of the cultural attribution of the antiquities of the presentday Smolensk land, the authors attribute these settlements to a wide range of types of Tushemli and Kolochin. A ceramic set is considered to be most responsible for cultural attribution, while Demidovka is one of the most important cultural standards of its time.

The research of the fortified settlement of Demidovka was initiated by Liavdanskii ${ }^{1}$ (Table 37 ).

${ }^{1}$ Liavdanskii A.N., 1924. Materialy dlia arkheologicheskoi karty Smolenskoi gubernii [Materials for the archaeological map of Smolensk Province] // Trudy smolenskikh gosudarstvennykh muzeev [Research works of Smolensk state museums]. Issue 1. Smolensk, 1924. P. 127-184. (In Russ.) 

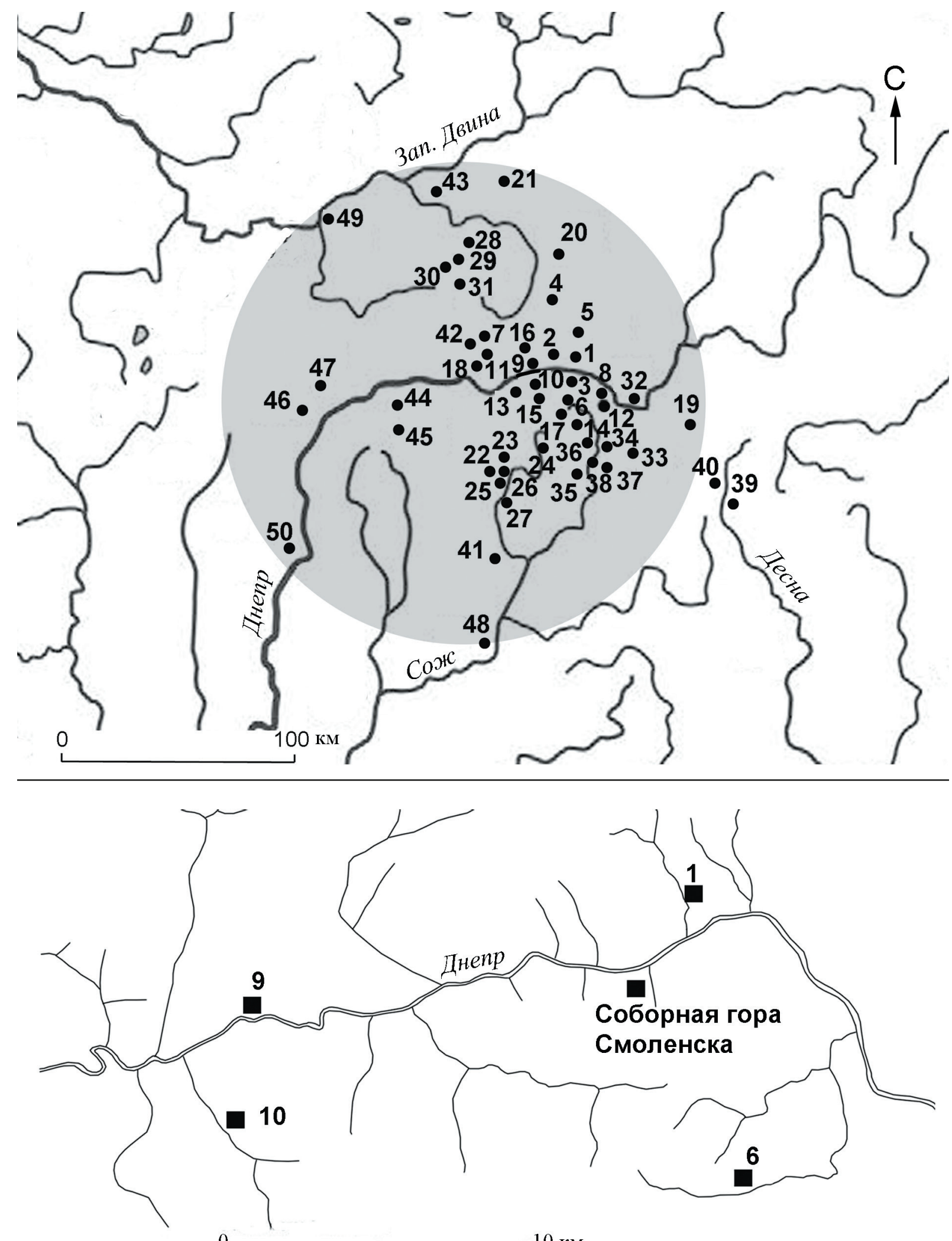

0

$10 \mathrm{KM}$

Fig. 1. Map of fortified settlements of the $5^{\text {th }}-7^{\text {th }}$ centuries AD belonging to the "Demidovka circle", numbering corresponds to Table 1; the inset shows the Smolensk district 
Table 1. Data on fortified settlements of the middle of $1^{\text {st }}$ millennium AD in the Western Smolensk land and in Eastern Belarus

\begin{tabular}{|c|c|c|c|}
\hline Number*, name & Size & $\begin{array}{l}\text { Excavation area }\left(\mathrm{m}^{2}\right) \\
(\text { excavation author and } \\
\text { period) })^{* *}\end{array}$ & Status finds \\
\hline \multicolumn{4}{|c|}{ Smolensk Region } \\
\hline 1 (3). Vyazovenka & $\begin{array}{l}90 \times 48+\text { ancient } \\
\text { settlement }\end{array}$ & $\begin{array}{l}3 \text { (Krenke, 2017); } \\
16 \text { (Modestov, 2004) }\end{array}$ & $\begin{array}{l}\text { Silver hryvnia, } \\
\text { brooch rimmed with } \\
\text { bird heads }\end{array}$ \\
\hline 2 (5). Lestrovka & $50 \times 40$ & & \\
\hline 3 (6). Rachevskoye & $25 \times 15$ & & \\
\hline 4 (19). Abramkovo & $40 \times 12$ & & \\
\hline 5 (32). Bliznaki & $42 \times 40$ & 400 (Schmidt, 1970-1973) & $\begin{array}{l}\text { Silver bracelet, spears, } \\
\text { arrows, bits, spurs }\end{array}$ \\
\hline 6 (35). Bogoroditskoye & $\begin{array}{l}47 \times 34+1 \text { ancient settle- } \\
\text { ment }(200 \times 30)\end{array}$ & $\begin{array}{l}96 \text { (Modestov, 1989); } \\
1 \text { (Krenke, 2019) }\end{array}$ & \\
\hline 7 (57). Volokovaya & $22 \times 18$ & & \\
\hline 8 (64). Vysokoye & $60 \times 20$ & & \\
\hline 9 (79). Gnezdovo & $115 \times 98$ & $\begin{array}{l}\text { 2,500 (Andreev, Avdusin, } \\
\text { Pushkina, 1940-2014) }\end{array}$ & \\
\hline 10 (81). Demidovka & $\begin{array}{l}50 \times 30+\text { ancient } \\
\text { settlement }\end{array}$ & 1,076 (Schmidt) & $\begin{array}{l}\text { Silver belt, rings, } \\
\text { ingot, spears, spurs }\end{array}$ \\
\hline 11 (92). Ermaki & $32 \times 28$ & & \\
\hline $\begin{array}{l}12 \text { (106). Znamenka } \\
\text { (Voishchina/Tserkovishche) }\end{array}$ & $50 \times 31$ & 1,052 (Sedov) & Silver pectoral \\
\hline 13 (168). Kushlyanshchina & $28 \times 26$ & & \\
\hline 14 (180). Lakhteevo & $60 \times 25$ & Liavdanskii & \\
\hline 15 (182). Lubnia & $24 \times 25$ & & \\
\hline 16 (200). Noviye Bateki & $48 \times 23$ & 850 (Schmidt, 1959, 1960) & \\
\hline 17 (211). Ray & Diameter of $24 \mathrm{~m}$ & & \\
\hline 18 (235). Staroye Kuprino & $19 \times 15$ & & \\
\hline 19 (338). Boltutino & $60 \times 45$ & & \\
\hline 20 (424). Akatovo & $\begin{array}{l}20 \times 1616 \times 1216 \times 13 \\
+ \text { ancient settlement }\end{array}$ & 560 (Schmidt, 1958-1960) & \\
\hline 21 (470). Klyuch & $22 \times 13$ & & \\
\hline 22 (660). Bokhot & $45 \times 40$ & & \\
\hline 23 (666). Yegorye & Diameter of $25 \mathrm{~m}$ & & \\
\hline 24 (680). Moshchinovo & $50 \times 40$ & & \\
\hline 25 (681). Nazimki & $50 \times 40$ & & \\
\hline 26 (682). Perepechino & $35 \times 25$ & & \\
\hline 27 (685). Ray & $40 \times 60$ & & \\
\hline 28 (712) Kovali & $30 \times 8$ (destroyed $)$ & & \\
\hline $\begin{array}{l}29 \text { (718). Fortified settle- } \\
\text { ment of Mikulino } 1\end{array}$ & $\begin{array}{l}67 \times 33+\text { ancient } \\
\text { settlement }\end{array}$ & 32 (Schmidt, 1980) & \\
\hline 30 (738). Samsontsy & $45 \times 38$ & 514 (Schmidt, 1980-1985) & Spear \\
\hline 31 (744). Khotezh & $48 \times 43$ & & \\
\hline $\begin{array}{l}32 \text { (1023). Verkhniye } \\
\text { Nemykary }\end{array}$ & $29 \times 18$ & & \\
\hline 33 (1034). Gorodok & $32 \times 26$ & 104 (Tret'iakov) & \\
\hline 34 (1055). Kolychevo & $35 \times 30$ & $20(-"-)$ & \\
\hline $\begin{array}{l}35 \text { (1072). Mokryadino } \\
\text { (Tushemlya) }\end{array}$ & $35 \times 32$ & $750(-“-)$ & Spear \\
\hline
\end{tabular}




\begin{tabular}{|c|c|c|c|}
\hline $\begin{array}{l}36 \text { (1108). Pokrovskoye } \\
\text { (Kovsharovskoye) }\end{array}$ & $60 \times 70$ & 100 (Liavdanskii) & \\
\hline 37 (1114). Prudky 1 & $35 \times 27$ & 16 (Tret'iakov) & \\
\hline $\begin{array}{l}38 \text { (1137). Glushitsa } \\
\text { Sloboda }\end{array}$ & $20 \times 17$ & 395 (Tret'iakov) & \\
\hline 39 (1175). Bogdanovo & $45 \times 35$ & 900 (Schmidt, 1976-1978) & \\
\hline 40 (1259). Kholmets & $48 \times 35$ & $\begin{array}{l}900 \text { (Tret'iakov, E.A. } \\
\text { Schmidt) }\end{array}$ & \\
\hline 41 (1438). Elovtsy & $35 \times 27$ & & \\
\hline 42 (225). Smolino & $28 \times 1115 \times 8$ & & \\
\hline \multicolumn{4}{|c|}{43 (1592). Kolotovshchina 1} \\
\hline \multicolumn{4}{|c|}{ Belarus } \\
\hline 44. Vezhki & $\begin{array}{l}68 \times 41+\text { ancient } \\
\text { settlement }\end{array}$ & 320 (Kolosovskii) & $\begin{array}{l}\text { Silver temple and } \\
\text { triangular pendants; } \\
\text { ring; spear, arrows, } \\
\text { spur }\end{array}$ \\
\hline 45. Nikodimovo & $120 \times 30$ & 1,058 (Sedin, 1986-2004) & $\begin{array}{l}\text { Silver bracelet, belt set } \\
\text { with silver inlay }\end{array}$ \\
\hline 46. Kiseli & $42 \times 32$ & 168 (Levko, 1988, 1989) & \\
\hline 47. Cherkasovo & $55 \times 45$ & $\begin{array}{l}65 \text { (Dubinskii, 1928); } 60 \\
\text { (Levko, 1989) }\end{array}$ & \\
\hline $\begin{array}{l}\text { 48. Krichev (Gorodets } \\
\text { Mountain) }\end{array}$ & $50 \times 25$ (destroyed $)$ & 214 (Miatselskii) & \\
\hline 49. Vitebsk & & 14,000 (Buben’ko, Levko) & \\
\hline 50. Mogilev (Zmeevka) & $55 \times 30$ & 44 (Marzaliuk, 2008) & \\
\hline
\end{tabular}

Note: *The number in parentheses is according to: Archaeological map..., 1997; **Years of excavations or their area are not indicated if there is no corresponding information.

Then the site of this fortified settlement was almost completely excavated by Schmidt in 1957, 19611967. In 2004, a small excavation site was studied by Modestov in the fortified settlement of Vyazovenki.

The materials of Demidovka were partially introduced into scientific circulation ${ }^{2}$, and the materials of the fortified settlement of Vyazovenki have not been previously published. Despite the incompleteness of the published materials of

${ }^{2}$ Ambroz A.K. Iuzhnye khudozhestvennye sviazi naseleniia Verkhnego Podneprov'ia v VI v. [Southern artistic ties of the of the Upper Dnieper population in the $6^{\text {th }}$ century] $/ /$ Kukharenko Yu.V. (Ed.), Drevnie slavyane i ikh sosedi [Ancient Slavs and their neighbours]. Moskva, 1970. P. 7074. (In Russ.); Schmidt E.A. Nekotorye arkheologicheskie pamiatniki Smolenshchiny vtoroi poloviny I tys. n.e. [Some archaeological sites of the Smolensk land of the second half of the $1^{\text {st }}$ millennium AD] // Rybakov B.A. (Ed.), Slaviane nakanune obrazovaniia Kievskoi Rusi [Slavs on the eve of the formation of Kievan Rus]. Moskva, 1963. P. 51-67. (In Russ.); Schmidt E.A. O kul'ture gorodishch-ubezhishch levoberezhnoi Smolenshchiny [About the culture of refuge fortified settlements in the left-bank Smolensk land] // Kukharenko Yu.V. (Ed.), Drevnie slaviane i ikh sosedi [Ancient Slavs and their neighbours]. Moskva, 1970. P. 6369. (In Russ.); Schmidt E.A. Tushemlinskaia kul'tura [The Tushemlya culture]. Smolensk, 2003. (In Russ.)
Demidovka, due to their paramount importance, researchers have repeatedly been involved in discussing the problems of interaction of different ethnic (including Central European, Germanic, Slavic) cultural traditions in the forest zone during the era of migration period ${ }^{3}$. The relevance

3 Akhmedov I.R., Kazanskii M.M. Posle Attily. Kievskii klad i ego kul'turno-istoricheskii kontekst [After Attila. The Kiev hoard and its cultural and historical context] // Goryunova V.M., Shcheglova O.A. (Eds.), Kul'turnye transformatsii i vzaimovliianiia v Dneprovskom regione na iskhode rimskogo vremeni i v rannem Srednevekov'e [Cultural transformations and mutual influences in the Dnieper region at the end of Roman period and in the early Middle Ages]. Sankt-Peterburg, 2004. P. 168-202. (In Russ.); Akhmedov I.R. Nekotorye indikatory kul'turnykh vzaimodeistvii v drevnostiakh riazano-okskikh finnov vtoroi poloviny $\mathrm{V}$ - nachala VI v. [Some indicators of cultural interactions in antiquities of the Ryazan-Oka Finns of the second half of the $5^{\text {th }}$-early $6^{\text {th }}$ century] $/ /$ Oblomskii A.M. (Ed.), Problemy vzaimodeistviia naseleniia Vostochnoi Evropy v epokhu Velikogo pereseleniia narodov [Issues of interaction between the population of Eastern Europe in the Migration Period]. Moskva, 2014. P. 138-177. (In Russ.); Kazanskii M.M. Prestizhnye nakhodki i tsentry vlasti postgunskogo vremeni v Podneprov'e [Prestigious finds and post-Hunnic centres of power power in the Dnieper region] // Stratum plus. 2018. No. 4. P. 83-118. (In Russ.) 
of preparing a monographic publication about Demidovka was emphasized by Schmidt (the interview at the Stuff of the IA RAS Smolensk expedition in Smolensk on October 2, 2014), as well as by Oblomskii, who systematically used the materials of this site when characterizing the Kolochin culture ${ }^{4}$.

The purpose of this article is to present materials that are still few in number, obtained during the initial stage of exploration of the immediate vicinity of these two fortified settlements, and to outline new lines of research.

The three issues in the title of the article are debatable, but only two of them were most actively developed: on the cultural attribution and chronology of the sites of the Smolensk land in the era of migration period ${ }^{5}$.

The first issue was previously little-discussed if it is possible to identify a certain hierarchy among the fortified settlements of the Smolensk land in the middle - third quarter of the $1^{\text {st }}$ millennium AD, which would be manifested in their size, features of fortification, the structure of monuments, the composition of finds, the degree of anthropogenic landscape restructuring.

When determining the spatial-chronological research framework, the following approach was applied. Fortified settlements were taken into account, where researchers found materials of the middle - third quarter of the $1^{\text {st }}$ millennium $\mathrm{AD}$ (they used to be denoted in literature as the

4 Oblomskii A.M. Kolochinskaia kul'tura [The Kolochin culture] // Oblomskii A.M., Islanova I.V. (Eds.), Rannesrednevekovye drevnosti lesnoi zony Vostochnoi Evropy V-VII vv. [Early medieval antiquities from the forest zone of Eastern Europe of the $5^{\text {th }}-7^{\text {th }}$ centuries]. Moskva, 2016. P. 10-113. (In Russ.)

5 See the main historiography in Lopatin N.V. The Tushemlya and Kolochin cultures // Rodinkova V.E., Rumyantseva O.S. (Eds.), Evropa ot Latena do Srednevekov'ya: varvarskiy mir i rozhdenie slavyanskikh kul'tur: K 60-letiyu A.M. Oblomskogo [Europe from La Tène to the Middle Ages: the barbaric world and the birth of Slavic cultures: To the $60^{\text {th }}$ anniversary of A.M. Oblomsky]. Moskva, 2017. P. 63-69. (In Russ.); Furas'ev A.G. Demidovka i Uzmen'. "Netraditsionnyi vzgliad" na "klassicheskie" pamiatniki [Demidovka and Uzmen. "An unconventional view" of the "classical" sites] // Belarus' u sisteme ey̆rapeyskikh kul'turnykh suvyazyay̆ [Belarus in the framework of European cultural ties]. Minsk, 1997. P. 33-38. (In Russ.); Furas'ev A.G. $\mathrm{O}$ datirovke i proiskhozhdenii odnoi gruppy priazhek epokhi velikogo pereseleniia narodov [On the dating and origin of one group of buckles of the Great Migration period] // Soobshcheniya Gosudarstvennogo Ermitazha [Transactions of the State Hermitage Museum]. No. LIX Sankt-Peterburg, 2001. P. 24-27. (In Russ.)
"Tushemlin" or "Kolochin" culture). Geographic boundaries are the districts of the fortified settlement of Demidovka with a radius of about $100 \mathrm{~km}$, the sites were not plotted on the map outside the outlined circle (Fig. 1).

In total, about 50 fortified settlements with materials from the analyzed period were registered in this region (Table 1). Linear measurements are the simplest parameter to record for comparing the sizes of fortified settlements. Measurement data are given in the Russian Archaeological Map of the Smolensk Region ${ }^{6}$, as well as in the publications of Belarusian colleagues ${ }^{7}$. Most of the fortified settlements are located within the interval with dimensions of $30 \times 35-60 \times 45 \mathrm{~m}$. A series of sites with lower values are the so-called bog fortified settlements; their functional specificity remains unknown. Several sites are larger in size. These are the fortified settlements of Gnezdovo, Nikodimovo, Vyazovenki. The fortified settlement of Gnezdovo should be immediately removed from this list, since only the size of the $10^{\text {th }}$-century site is known; there is very little published information about the earlier settlement that was in its place. The shape of sites of the fortified settlements of Nikodimovo and Vyazovenki is elongated (Fig. 2); the actual buildable area of these sites was not much larger than that of others. The site of the fortified settlement of Demidovka (Fig. 3) is included in the medium-sized group.

The second parameter to be taken into account is the availability or lack of an additional open settlement near the fortified settlement. Such settlements were discovered near some of the analyzed sites, including near the fortified settlements of Vyazovenki and Demidovka. The

${ }^{6}$ Krasnov Yu.A. (Ed.). Arkheologicheskaia karta Rossii. Smolenskaia oblast' [Archaeological map of Russia. Smolensk Region]. Moskva, 1997.

7 Levko O.N., Kolosovskii Yu.V. Raskopki gorodishch u d. Kiseli (Dymokury) Tolochinskogo raiona i u d. Cherkasovo Orshanskogo raiona Vitebskoi oblasti [Excavations of fortified settlements near the village of Kiseli (Dymokury), Tolochin district, and the village of Cherkasovo, Orsha district of Vitebsk Region] // Rannie slaviane Belorusskogo Podneprov'ia i Podvin'ia [Early Slavs of Belarusian area of the Dnieper and Dvina River regions]. Minsk, 2003. P. 182-208. (In Russ.); Miatsel'ski A.A. Staraday̆ni Krychay̆ [Old Krychau]. Minsk, 2003. (In Belarussian); Marzaliuk I. Novyia krynitsy pa gistoryi slavianskaga rassialennia y̆ magiley̆skim Padniproy̆i i Pasozhzhy [New sources on the history of Slavic settlement in Mogilev area of the Dnieper and Posozh River regions] // Gistarychnaarkhealagichny zbornik [Historical and archaeological collection of papers]. No. 26. Minsk, 2011. P. 97-118. (In Belarussian) 


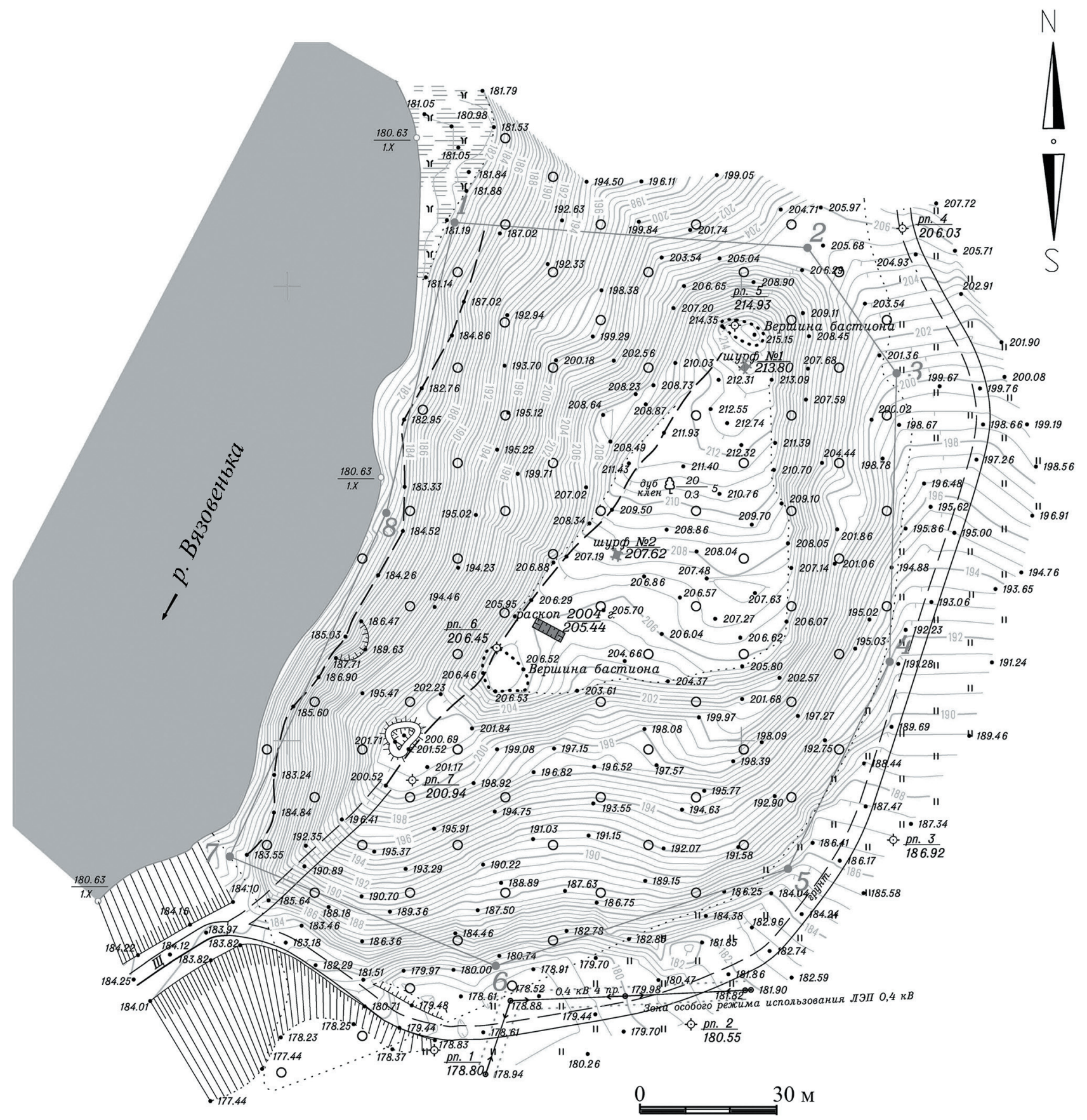

Fig. 2. Plan view of the fortified settlement of Vyazovenki, the survey of 2017

ancient settlement near the fortified settlement of Vyazovenki is located in the floodplain on the opposite bank of the Vyazovenki River, its size is now impossible to determine, as it is badly destroyed by the mill pond. On the southern side of the fortified settlement of Demidovka, test-pits have revealed a cultural layer with rare fragments of ceramics. The nature of this site is still unclear, no buildings have been found, but a cultural layer (in some places up to $1 \mathrm{~m}$ thick) indicates an intensive economic life.
The power of defensive fortifications varies greatly. There are fortified settlements with ramparts of impressive size, in which the excess of the rampart ridge over the ditch bottom reaches $9 \mathrm{~m}$ (Kiseli, Vyazovenki, Bogoroditskoe). However, these sites are multi-layered and there is no clarity in the construction history of defensive structures. The Demidovka rampart has average parameters; its height is only $2 \mathrm{~m}$.

The most important distinguishing feature of the fortified settlement of Demidovka is a building 

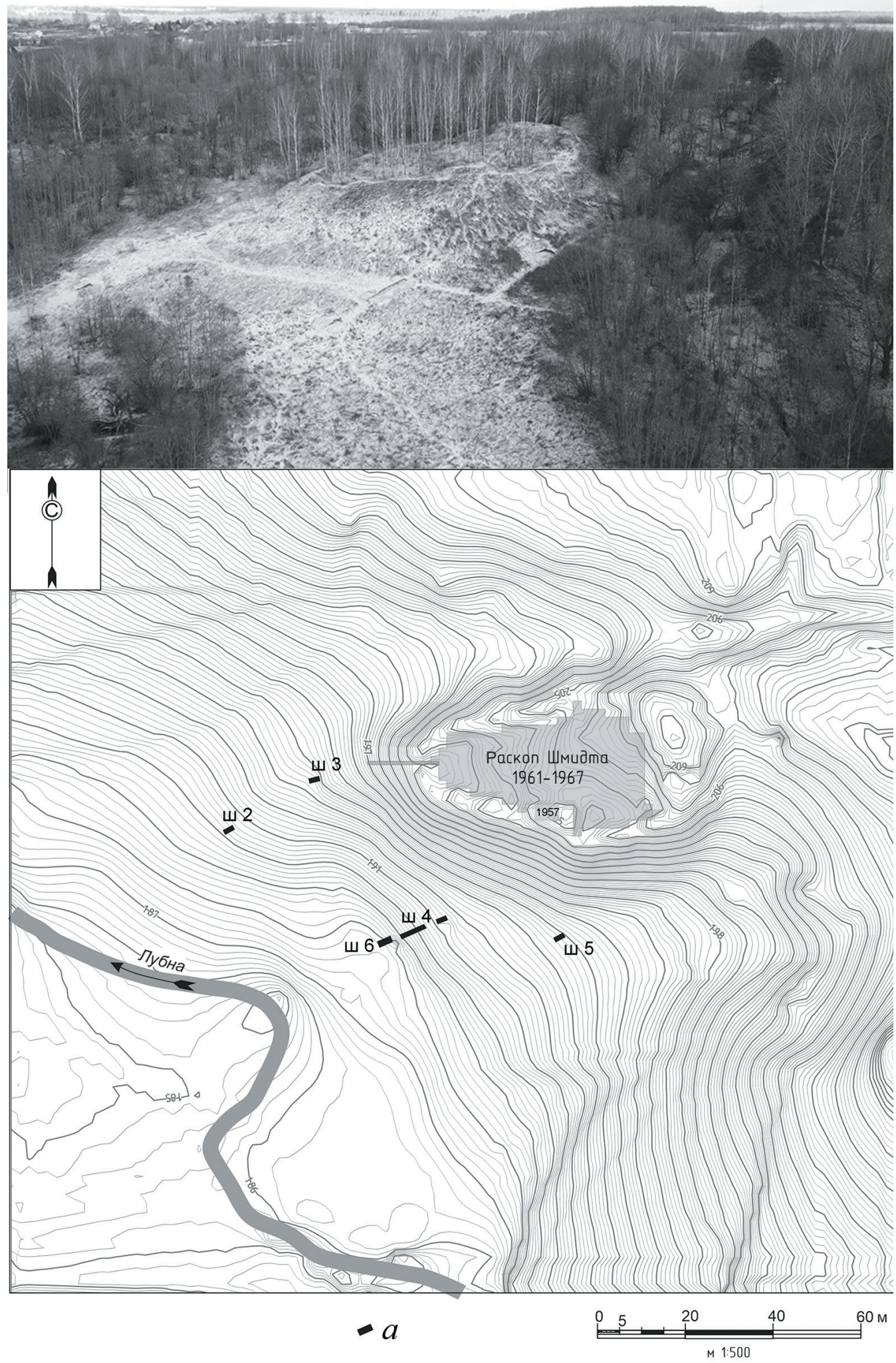

Fig. 3. A view of the fortified settlement of Demidovka from the southwest (above) and the plan of the fortified settlement of Demidovka, the author K.A. Ganichev, 2020. Symbol: $a$ - pits in 2019. The contours are drawn every $0.2 \mathrm{~m}$. Conditional coordinate system 


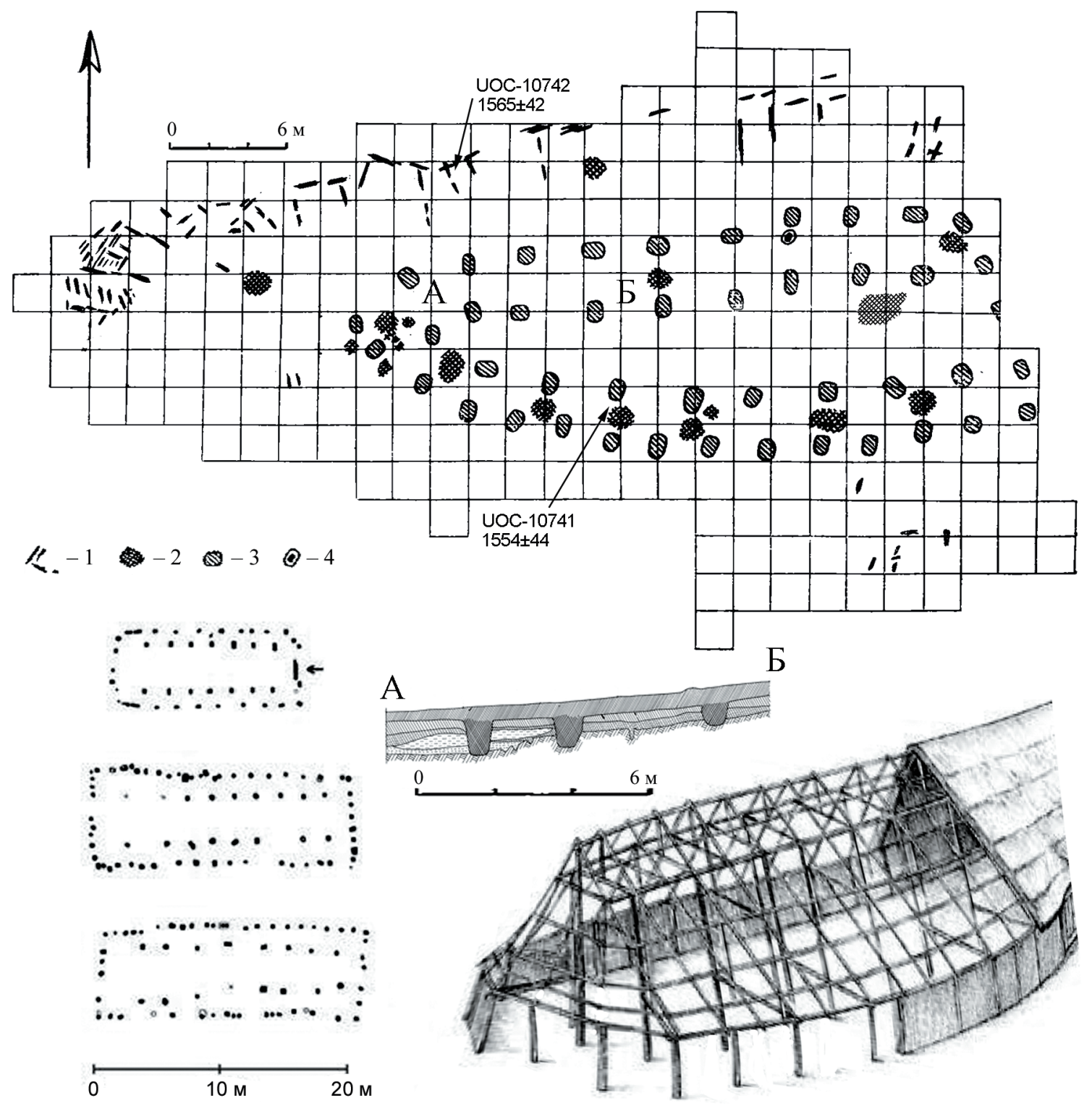

Fig. 4. Plan view of a structure at the fortified settlement of Demidovka (after: Schmidt, 1970, corrected according to reports). Symbols: 1 - burnt-out wooden structures; 2 - hearts; 3 - pole pits; 4 - stone grain grater. Below are plans of similar structures excavated in the northeast of the Netherlands ("Wijster type") and the structural scheme of the buildings (after: Nüsse, 2014)

found in the upper layer. It is traced in the form of four rows of pillar pits and breakdowns of hearth stones between them (Fig. 4). The author of excavations Schmidt interpreted these remains as two different buildings of a similar design long narrow houses with dimensions of $2.5 \times 38$ and $3.5 \times 34 \mathrm{~m}$, between which there was a courtyard, possibly partially covered with a roof $^{8}$.

8 Schmidt E.A. O kul'ture gorodishch-ubezhishch levoberezhnoi Smolenshchiny [About the culture of refuge fortified settlements in the left-bank Smolensk land] // Kukharenko Yu.V. (Ed.), Drevnie slaviane i ikh sosedi [Ancient Slavs and their neighbours]. Moskva, 1970. P. 64. (In Russ.)
Familiarization with the reporting documentation allows putting forward a different interpretation. First, it should be noted that all the pillars were the same - about $30-35 \mathrm{~cm}$ in diameter, dug to a depth of $1 \mathrm{~m}$ (Fig. 4), i.e. the height of the walls was at least $2.5-3 \mathrm{~m}$. Second, "buildings" mentioned by Schmidt have no pillars along the axial lines, it is unclear how the ridge of the roof would be fixed. These features distinguish this structure from buildings on other fortified settlements. For example, at the fortified settlement of Nikodimovo ( $7^{\text {th }}$ century), where a building with similar pillars was found, the system of their location is different. With the width of 
the building about $4 \mathrm{~m}$, three rows of pillars were traced in its plan. The ridge of the roof was apparently held on the pillars of the centerline?.

It can be imagined that at the fortified settlement of Demidovka there was one building $12 \times 38 \mathrm{~m}$ in size, which had three "naves": two side naves with a width of $2.5-3.5 \mathrm{~m}$ and a wider central one (up to $6 \mathrm{~m}$ ). The outer contour includes 27 pillars, the inner one -17 . Long houses, divided into three longitudinal parts, are most common in the territory of the Netherlands, Germany, and South Scandinavia in the first half of the $1^{\text {st }}$ millennium AD. "Wijster type" houses (Fig. 4), excavated in the north-east of the Netherlands, are especially close in layout to the building from Demidovka ${ }^{10}$. Additional arguments in favor of such reconstruction are hearth debris in the central nave and pillars at the sidewalls of the dwelling, which connect the two side naves. It should be noted that such a large long house has not yet found analogies at other fortified settlements of the Smolensk Region and emphasizes the uniqueness of Demidovka.

When analyzing the composition of the finds, it is first necessary to mention the sites where silver jewelry was found. There are only six of them (Vyazovenki, Demidovka, Bliznaki, Tserkovishche, Nikodimovo, Vezhki). A piece of jewelry from the fortified settlement of Tserkovishche ${ }^{11}$ probably dates back to an earlier time than the middle of the $1^{\text {st }}$ millennium AD. Demidovka comes first among the five remaining fortified settlements, as a series of silver jewelry was found there. The fortified settlement of Vyazovenki can potentially compete with Demidovka, but too small area has been excavated on Vyazovenki. At all sites, except for Vyazovenki, silver jewelry is found along with horseman's weapons and equipment.

Besides, attention should be paid to items of "professional" weapons and equipment, such as a sword from Nikodimovo, pikes for equestrian combat from Bliznaki and Nikodimovo, a throwing

\footnotetext{
9 Sedin A.A. Predmety vooruzheniia, snariazheniia vsadnika i verkhovogo konia iz gorodishcha Nikodimovo [Weaponry, horseman and horse gear from the fortified settlement of Nikodimovo]. Mogilev, 2012. P. 7. (In Russ.)

${ }^{10}$ Nüsse H.-J. Haus, Gehцft und Siedlung im Norden und Westen der Germania magna. Rahden, 2014. P. 92.

11 Sedov V.V. Gorodishche Tserkovishche [The fortified settlement of Tserkovishche] // Kratkie soobshcheniia Instituta arkheologii [Brief Communications of the Institute of Archaeology]. 1964. Issue 102. P. 72. (In Russ.)
}

battle ax - "Francis" - from Demidovka" ${ }^{12}$. All these things are not related to everyday peaceful life and rather indicate professional soldiers staying in these settlements ${ }^{13}$.

The special significance as a social marker of some of the finds from Demidovka has already been noted. This is a kidney-shaped buckle decorated with eagle heads (Fig. 5, 5), its analogies are found in chieftains' burials of Western and Central Europe ${ }^{14}$. According to Ambroz, in the Upper Dnieper, there was a center for the manufacture of similar items ${ }^{15}$. This conclusion, supported by further research ${ }^{16}$, indicates that an exclusive "military" buckle got into the layers of Demidovka not coincidentally.

Attention is also drawn to a typeset belt with narrow overlays-plates (Fig. 5, 2). There are 103 of them in the collection. The plates were attached to the belt with iron cotter pins, the holes were decorated with silver caps. Such belts were widespread in the era of migration period,

12 Kazanskii M.M. Vooruzhenie i konskoe snariazhenie slavian V-VII vv. [Armament and horse equipment of the Slavs of the $5^{\text {th }}-7^{\text {th }}$ centuries] $/ /$ Stratum plus. 2015. No. 5 . P. 47, 49, 51, 65-67. (In Russ.)

13 Kazanskii M.M. O poiasakh s nakladnymi uzkimi plastinami iz mogil'nika Luchistoe [Belts with applied narrow plaques from the Luchistoye cemetery] // Khairedinova E.A. (Ed.), Problemy istorii i arkheologii srednevekovogo Kryma: materialy mezhdunar. konf., posviashch. 70-letiiu A.I. Aibabina [Aspects of the history and archaeology of medieval Crimea: Proceedings of the International Conference to the $70^{\text {th }}$ Anniversary of A.I. Aybabin]. Simferopol, 2019. P. 60-64. (In Russ.)

14 Kazanskii M.M. Prestizhnye nakhodki i tsentry vlasti postgunskogo vremeni v Podneprov'e [Prestigious finds and post-Hunnic centres of power power in the Dnieper region] // Stratum plus. 2018. No. 4. P. 96. (In Russ.)

15 Ambroz A.K. Iuzhnye khudozhestvennye sviazi naseleniia Verkhnego Podneprov'ia v VI v. [Southern artistic ties of the of the Upper Dnieper population in the $6^{\text {th }}$ centuryl // Kukharenko Yu.V. (Ed.), Drevnie slavyane i ikh sosedi [Ancient Slavs and their neighbours]. Moskva, 1970. P. 70-74. (In Russ.)

16 Akhmedov I.R. Nekotorye indikatory kul'turnykh vzaimodeistvii $\mathrm{v}$ drevnostiakh riazano-okskikh finnov vtoroi poloviny $\mathrm{V}$ - nachala VI v. [Some indicators of cultural interactions in antiquities of the Ryazan-Oka Finns of the second half of the $5^{\text {th }}$-early $6^{\text {th }}$ century] $/ /$ Oblomskii A.M. (Ed.), Problemy vzaimodeistviia naseleniia Vostochnoi Evropy v epokhu Velikogo pereseleniia narodov [Issues of interaction between the population of Eastern Europe in the Migration Period]. Moskva, 2014. P. 138-177. (In Russ.); Kazanskii M.M. Prestizhnye nakhodki i tsentry vlasti postgunskogo vremeni v Podneprov'e [Prestigious finds and post-Hunnic centres of power power in the Dnieper region] // Stratum plus. 2018. No. 4. P. 95-103. (In Russ.) 

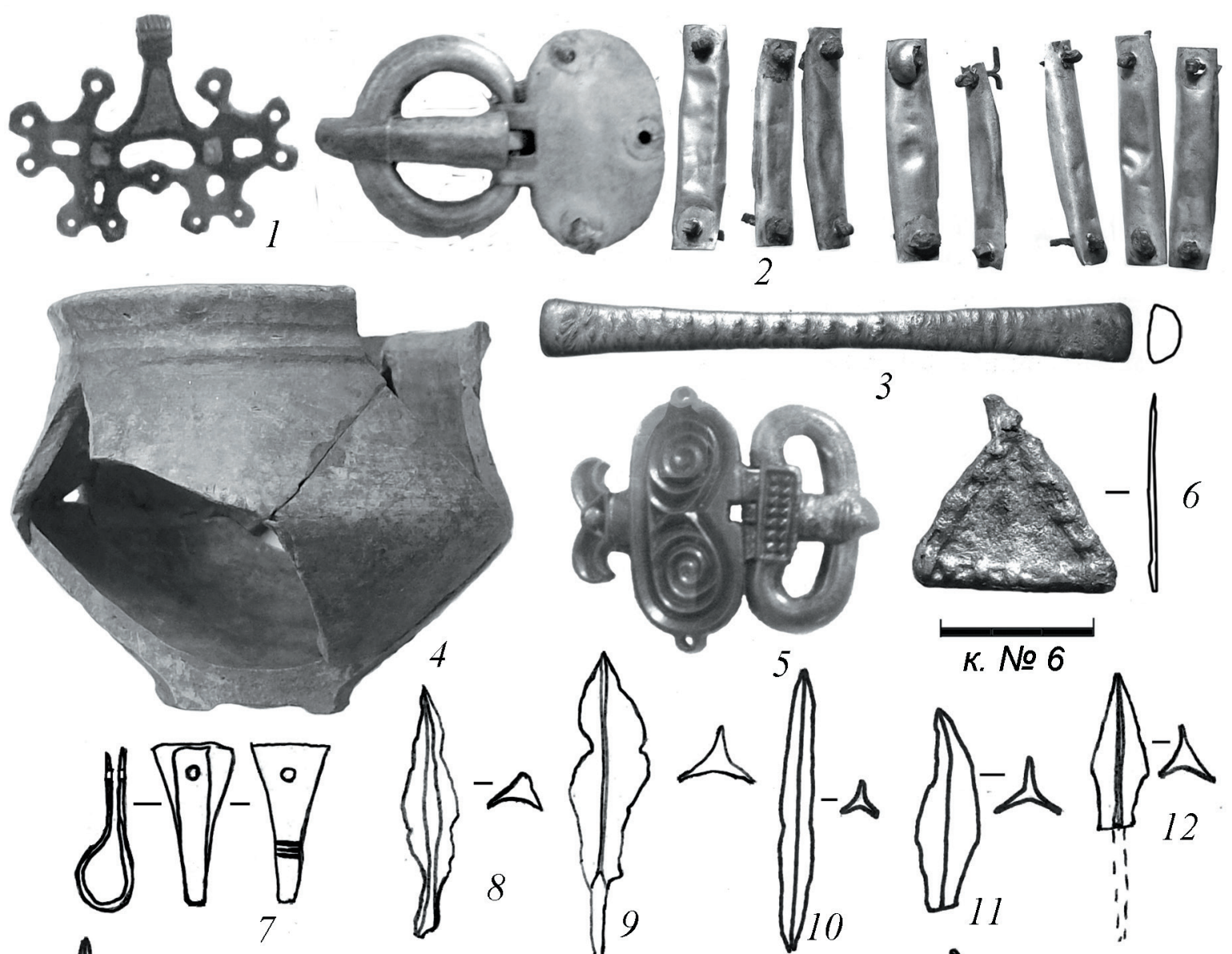

3
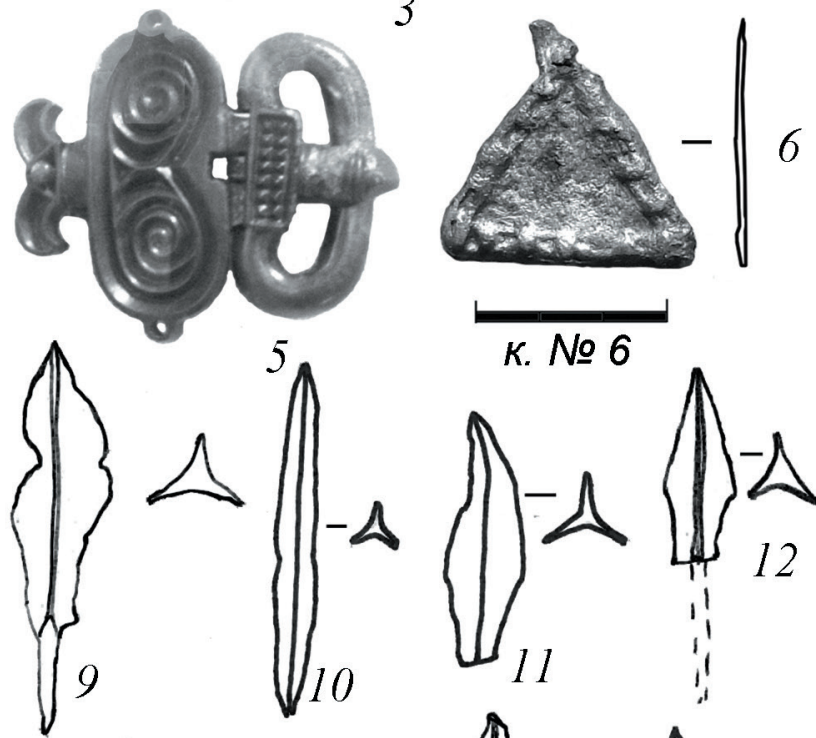

K. № 6
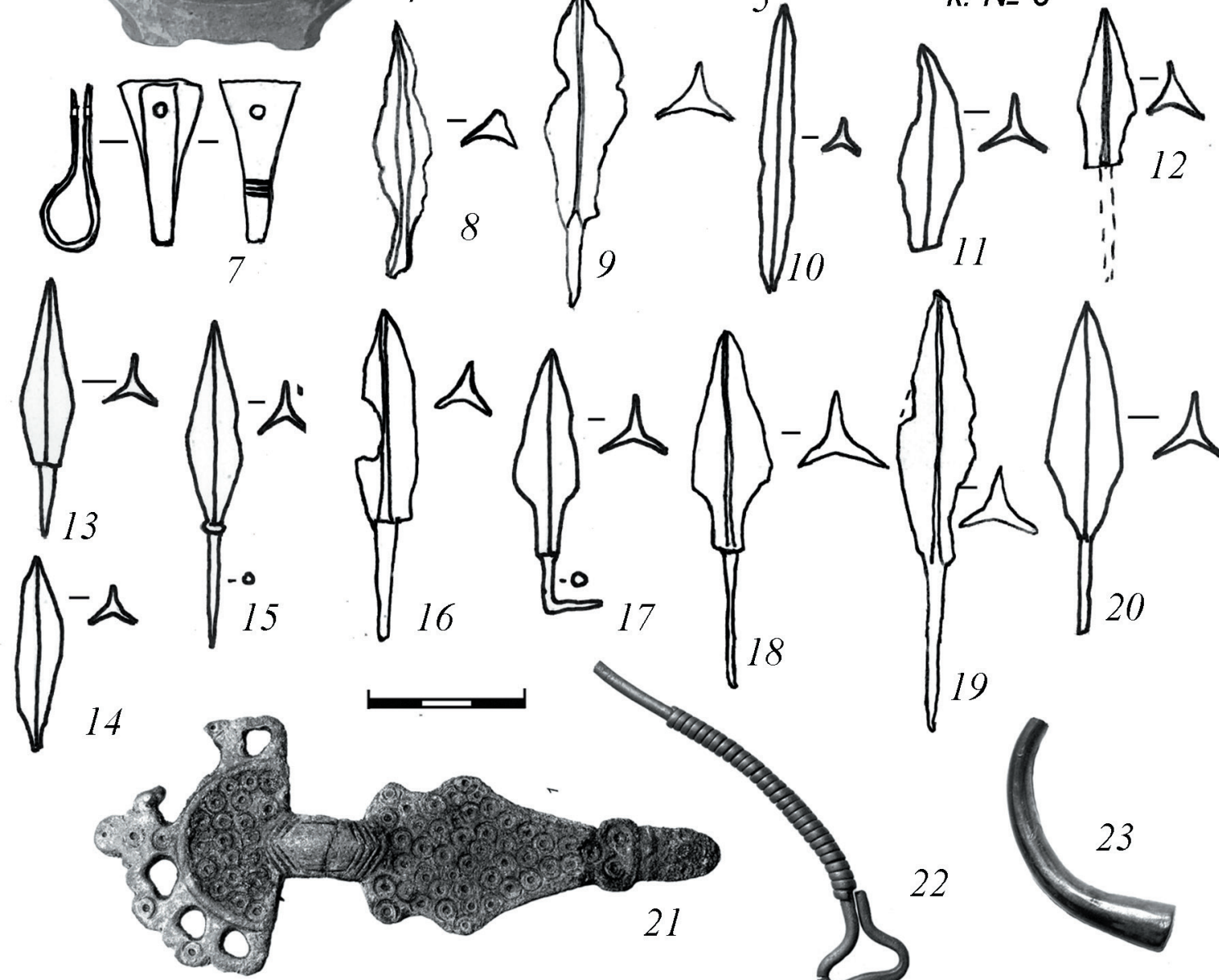

21
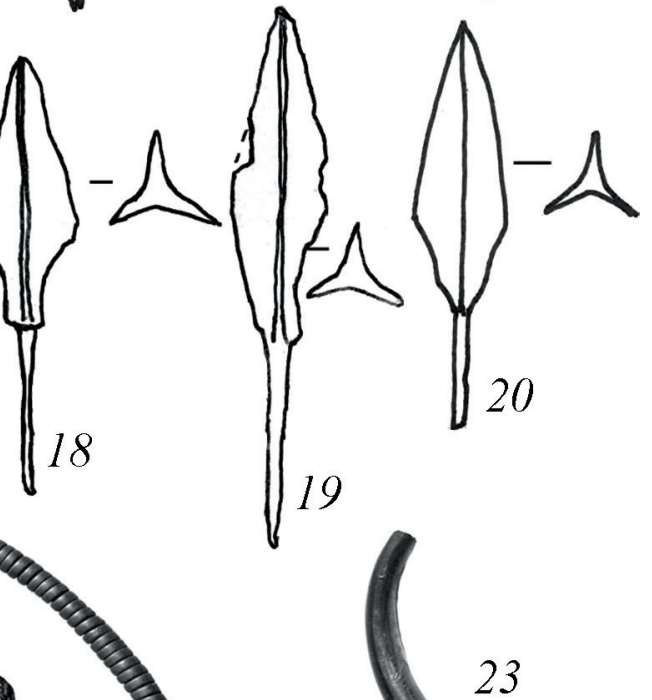

Fig. 5. Finds from the fortified settlements of Demidovka (1-20), Vyazovenki $(21,22)$ and Bliznaki $(23)$. 1 - enamel covered lunula; 2 - buckle and belt pads (105 pcs in total); 3 - ingot weighing $27.85 \mathrm{~g} ; 4$ - gray-polished goblet; 5 - buckle; 6 - ornamented plate; 7 - connection piece of a pendant; 8-20 - arrows. The finds are kept in the Smolensk Museum; 21, 22 - brooch and a fragment of a hryvnia; 23 - bracelet. 1 - bronze, enamel; 2, 3, 5, 6, 22, 23 - silver; 7-20-iron; 21 - bronze. $1-5$ - from excavations in the period of 1961-1967; 6-20 - from pits in 2019 


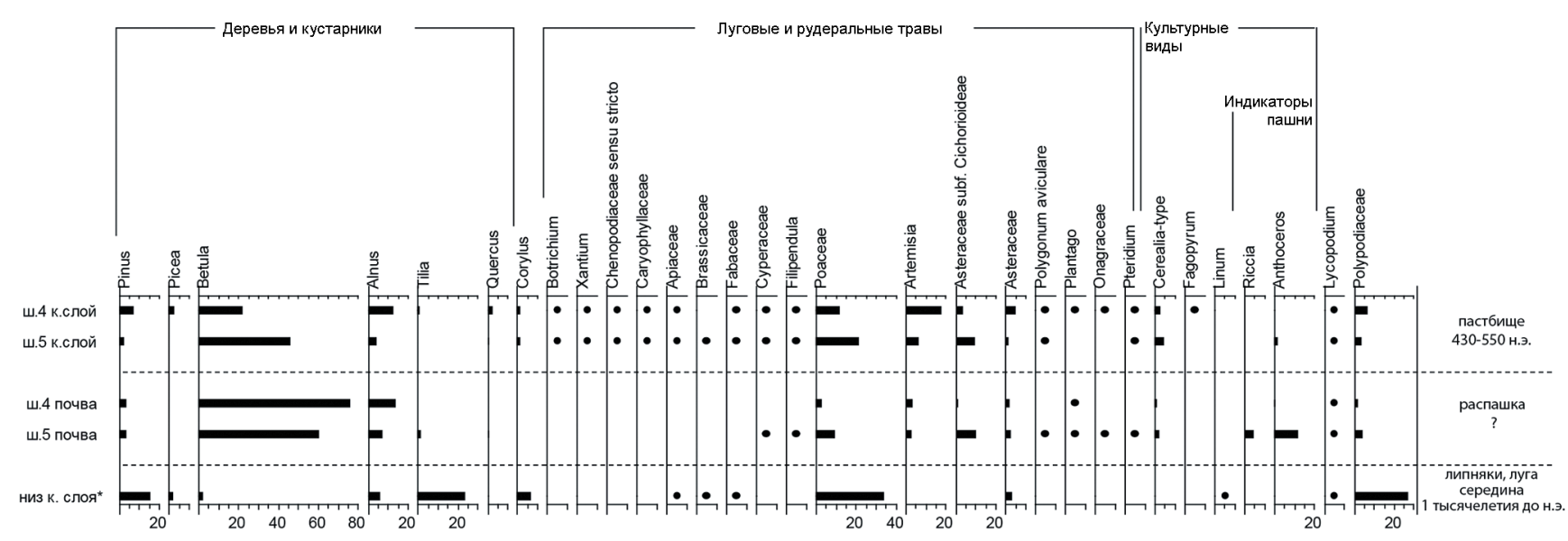

Fig. 6. The abridged spore-pollen diagram of the cultural layer and the soil buried under it in the test pits near the fortified settlement of Demidovka and in the settlement itself (after: Schmidt, 1992). Pollen taxa are presented in \% of the total pollen, spore ones - in $\%$ of the total of pollen and spores

the most splendid specimens are found in the area of the Roman borderlands, less often within the Empire (Tolna, Traprein-Lo, Lyon). It can be assumed that they reflect the influence of "limes" fashion, which covered both the population of the Roman provinces and the barbarians ${ }^{17}$. The find which is the closest to Demidovka is the Volnikovsky "treasure" of the first half of the $5^{\text {th }}$ century from Kursk Posemye ${ }^{18}$.

From among the new finds in 2019 in Demidovka, a silver triangular pendant should be noted. On all sides of the triangle, there is a series of points-bulges, the eyelet is broken off (Fig. 5, 6). Almost identical silver pendants were found at the fortified settlement of Vezhki, where they are dated to the third quarter of the $1^{\text {st }}$ millennium $\mathrm{AD}^{19}$ (Fig. 3). Gold and

17 Kazanskii M.M. O voennoi organizatsii slavian v VVII vekakh: vozhdi, professional'nye voiny i arkheologicheskie dannye [On the military organization of the Slavs in the $5^{\text {th }}-7^{\text {th }}$ centuries: leaders, professional warriors and archaeological data] // Stratum plus. 2019. No. 5. P. 1528. (In Russ.)

18 Radiush O.A., Shcheglova O.A. Volnikovskii klad 1-i poloviny $\mathrm{V}$ v. v kontekste sinkhronnykh drevnostei epokhi Velikogo pereseleniia narodov [The Volnikovka hoard of the first half of the 5th century in the context of synchronous antiquities of the Migration period] // Volnikovskii "klad" [The Volnikovka "hoard"]. Moskva, 2014. P. 4-25. (In Russ.)

19 Kolosovskii Yu.V. Gorodishche i selishche okolo derevni Vezhki Dubrovenskogo raiona Vitebskoi oblasti. Issledovaniia 1994-1998 gg. [A fortified settlement and a settlement near the village of Vezhki, Dubrovno district of Vitebsk Region. Research of 1994-1998] // Slaviane na territorii Belarusi v dogosudarstvennyi period [Slavs in the territory of Belarus in the pre-state period]. Book 1. Minsk, 2019. P. 336-344. (In Russ.) silver pendants/sew-on patches of this type were found in the Crimean Gothic burial grounds and date back to the $5^{\text {th }}$ century ${ }^{20}$ (Fig. 13, 15-19). Derivatives of this type of jewelry are well known at the sites in Belarus and North-West Russia (Nikodimovo, Staraya Ladoga, Izborsk, etc.) these are foundry molds and the items made from lead-tin alloys ${ }^{21}$ (Fig. 2, 5-16).

The features of the cultural landscape can also be considered as a parameter for distinguishing between ordinary and somewhat outstanding settlements. The dynamics of the cultural landscape around the fortified settlements can be reconstructed according to the data of the sporepollen analysis (Fig. 6). Pollen studies of cultural layers of the Dnieper-Dvina fortified settlements were first carried out in the early $1960 \mathrm{~s}^{22}$. In 2019 , these studies were continued by analyzing the soil sections at the foot of the fortified settlement of Demidovka; columns of samples were taken in test-pits 2, 4-6.

${ }^{20}$ Maczyńska M., Urbaniak A., Jakubczyk I. The early medieval cemetery of Almalyk-dere near the foot of Mangup. Inter Ambo Maria. Contacts between Scandinavia and the Crimea in the Roman Period. Kristiansand; Simferopol, 2011. P. 154-175.

21 Shcheglova O.A. Svintsovo-oloviannye ukrasheniia VIII-X vV. na severo-zapade Vostochnoi Evropy [Leadtin ornaments of the $8^{\text {th }}-10^{\text {th }}$ centuries in the northwest of Eastern Europe] // Kirpichnikov A.N. (Ed.), Ladoga i ee sosedi $v$ epokhu srednevekov'ia [Ladoga and its neighbours in the Middle Ages]. Sankt-Peterburg, 2002. P. 134-150. (In Russ.)

22 Schmidt E.A. Plemena verkhov'ev Dnepra do obrazovaniia drevnerusskogo gosudarstva [Tribes of the upper Dnieper region before the formation of the Rus state]. Moskva, 1992. P. 57-60. (In Russ.) 
The preliminary results of the analysis showed that the layers containing the finds of the late existence stage of the fortified settlement of Demidovka $\left(5^{\text {th }}-6^{\text {th }}\right.$ centuries) are similar to each other and are characterized by a low proportion of tree pollen (birch and alder) in combination with the abundance and diversity of grass pollen, among which there are many taxa typical for grazing, i.e. meadow and meadow-ruderal ones. It can be assumed that such composition of pollen, combined with an abundance of microscopic coal and burnt phytoliths, indicates an open space at the foot of the fortified settlement, used for pasture and supported by regular burning. This assumption is also supported by pollen from cultivated crops (presumably oats), which is typical for soils enriched with horse manure ${ }^{23}$.

The soil buried under the cultural layers in testpits 4 and 5, corresponding to an earlier stage in the existence of the fortified settlement, is noticeably different both in morphological features and in pollen spectra. It contains a lot of finerounded charcoal, and the pollen spectra are dominated by pollen and spores of forest plants. Besides, trees are represented almost exclusively by birch, while a few herbs are represented by weeds, cultivated crops, and species typical for the cleared and arable land. Probably, the earlier stages of development of the vicinity of the fortified settlement of Demidovka included the cutting down and burning of primary forests for plowing and the spread of secondary birch forests on overgrown arable lands.

It is interesting to compare the obtained spectra with the spectrum of the lower part of the cultural layer of the fortified settlement of Demidovka, obtained by Fedorova in the 1960s, and, apparently, reflecting the earliest, initial period of the settlement functioning, dated archaeologically to the middle of the $1^{\text {st }}$ millennium $\mathrm{BC}^{24}$. Among the trees, there are many lindens, while pollen of meadow grass, mainly crops, are most common, and flax pollen is found. This is interpreted by

${ }^{23}$ Ershova E.G., Bakumenko V.O., Vorontsov T.P., Goncharov M.M., Klimenko M.S., Kulikov N., Revokatova D.P., Selezneva E.M., Farish N.R., Fetisova E.S., Yakovenko E.P. Sporovo-pyl'tsevye spektry sovremennogo i srednevekovogo konskogo navoza [Spore-pollen spectra of modern and medieval manure dung] // Paleopochvy, paleoekologiia, paleoekonomika [Palaeosoils, palaeoecology, palaeoeconomics]. Pushchino, 2017. P. 70-74. (In Russ.)

${ }^{24}$ Schmidt E.A. Arkheologicheskie pamiatniki Smolenskoi oblasti (s drevneishikh vremen do VIII v. n.e.) [Archaeological sites of Smolensk Region (from the earliest times to the $8^{\text {th }}$ century AD)]. Smolensk, 1976. (In Russ.) the authors as the presence of open cultivated spaces around the fortified settlement by that time. However, as for the dominance of linden, the primary deciduous forests have not yet been completely cut down and replaced by secondary birch and pine forests.

According to the data set out above, settlements where people had a high status (these include those where silver was found) are not large in size, they are fitted in the dimensions of fortified settlements of the Early Iron Age. As a result an assumption can be made that the elite of the middle of the $1^{\text {st }}$ millennium $\mathrm{AD}$ was very active in moving around, its members received benefits not from the exploitation of the population brought to their place of residence, but controlled the villages relatively far from the "power centers". The abundance of finds of horseman's equipment may serve as an indirect confirmation of this hypothesis.

The presented materials (the largest number of silver finds, splendid cultural objects of "military" elites, "professional" weapons, a large long house of a "German type") make it possible to make a cautious assumption that the inhabitants of Demidovka stood out with a high social status among the inhabitants of other fortified settlements involved in the comparative analysis.

The chronology of fortified settlements of Demidovka and Vyazovenki is based on a series of artifacts and radiocarbon dates. As mentioned above, the lower layers of the fortified settlement of Demidovka date back to the second half of the $1^{\text {st }}$ millennium BC; typical Dnieper-Dvinian ceramics and related finds were discovered at the site $^{25}$. There are also ceramic materials from the horizon of the "middle layer of Tushemli", which may date back to the $2^{\text {nd }}$ century $\mathrm{BC}-2^{\text {nd }}$ century $\mathrm{AD}^{26}$. The materials of the $3^{\text {rd }}-4^{\text {th }}$ centuries $\mathrm{AD}$ include ceramics with combing and an enamelcovered lunula (Fig. 5, 1). Moreover, Demidovka is the only fortified settlement in the Smolensk land with the finds of this period. The scarcity

${ }^{25}$ Schmidt E.A. Arkheologicheskie pamiatniki Smolenskoi oblasti (s drevneishikh vremen do VIII v. n.e.) [Archaeological sites of Smolensk Region (from the earliest times to the $8^{\text {th }}$ century AD)]. Smolensk, 1976. P. 201 (In Russ.)

${ }^{26}$ Drobushevskii A. Etnokul'turnye izmeneniia v mezhdurech'e Dnepra i Desny na rubezhe nashei ery [Ethnic and cultural changes in the interfluve of the Dnieper and Desna at the dawn of the Common era] // Gistarychnaarkhealagichny zbornik [Historical and archaeological collection of papers]. No. 26. Minsk, 2011. P. 76-83. (In Russ.) 
Table 2. Radiocarbon dates of the fortified settlement of Demidovka

\begin{tabular}{|l|c|c|l|l|}
\hline Laboratory number & ${ }^{14}$ C-date & $\begin{array}{l}\text { Calibrated age, AD } \\
1 \sigma(68.2 \%)\end{array}$ & Material & Place of selection \\
\hline Le-727 & $1,570 \pm 70$ & $420-560$ & Coal & Top layer, sample 2 \\
\hline UOC-10741 & $1,554 \pm 44$ & $430-550$ & $\begin{array}{l}\text { Coal } \\
\text { (spruce) }\end{array}$ & $\begin{array}{l}\text { Fortified settlement } \\
\text { of Demidovka, } \\
\text { excavations by } \\
\text { Schmidt 1961, } \\
\text { square 7, layer 2, } \\
\text { a large long house }\end{array}$ \\
\hline UOC-10742 & $1,565 \pm 42$ & $430-540$ & $\begin{array}{l}\text { Coal } \\
\text { (spruce) } \\
\text { of Demidovka, } \\
\text { excavations by } \\
\text { Schmidt 1961, } \\
\text { square 35, layer 1, } \\
\text { a defensive wall cage }\end{array}$ \\
\hline UOC-10743 & $1,554 \pm 45$ & $430-550$ & Coal (millet grains) & $\begin{array}{l}\text { Fortified settlement of } \\
\text { Demidovka }\end{array}$ \\
\hline
\end{tabular}

of fragments of ceramics with combing, their fragmentation and small size indicate that they belong to a separate period in the history of the fortified settlement.

The main later period is represented by large fragments and ruins of non-decorated vessels. The most striking find dating back to the $3^{\text {rd }}$ $4^{\text {th }}$ centuries is a gray-polished Chernyakhov ceramic goblet (Fig. 5, 4). It has analogies in the Chernyakhov burial grounds of the $4^{\text {th }}$ century in the territory of Western Ukraine ${ }^{27}$ (Fig. 30, 7; Fig. 6, 2; Fig. 5, 7). It should also be noted that, according to Dobrzańska, this goblet is very similar in shape to Przeworsk vessels of $1 \mathrm{Bb}$

27 Nikitina G.F. Mogil'nik us. Oselivka Kel'menetskogo r-na Chernovitskoi obl. [A cemetery near the village of Oselivka, Kelmenetsi district of Chernivtsi Region] // Kropotkin V.V. (Ed.), Mogil'niki cherniakhovskoi kul'tury [Cemeteries of the Chernyakhov culture]. Moskva, 1988. P. 5-97. (In Russ.); Romanova G.A. Vily Iarugskie - mogil'nik IV v. n.e. [Vily Yarugskiye, a cemetery of the $4^{\text {th }}$ century AD] // Kropotkin V.V. (Ed.), Mogil'niki chernyakhovskoy kul'tury [Cemeteries of the Chernyakhov culture]. Moskva, 1988. P. 133-141. (In Russ.); Symonovich E.A. Pridunaiskii mogil'nik Furmanovka [The Danube cemetery of Furmanovka] // Kropotkin V.V. (Ed.), Mogil'niki cherniakhovskoi kul'tury [Cemeteries of the Chernyakhov culture]. Moskva, 1988. P. 164167. (In Russ.); Sharov O.V. Khronologiia mogil'nikov Ruzhichanka, Kosanovo, Dancheny i problema datirovki cherniakhovskoi keramiki [Chronology of the Ruzhichanka, Kosanovo, and Dancheny cemeteries and the problem of Chernyakhov pottery dating] // Shchukin M.B., Gey O.A. (Eds.), Problemy khronologii epokhi latena i rimskogo vremeni [Issues of chronology of La Tène and the Roman period]. Sankt-Peterburg, 1992. P. 158-207. (In Russ.) and 4B types from the Igolomiya settlement in the Krakow Voivodeship, which are attributed to chronological phases $\mathrm{C} 1 \mathrm{~b}-\mathrm{C} 2\left(3^{\text {rd }}-\right.$ early $4^{\text {th }}$ century $)^{28}$ (Tables XXIX, 3; XLIII, 8$)^{29}$.

The find of the second half of the $5^{\text {th }}-$ the turn of the $6^{\text {th }}$ century is an "East German" buckle with kerbshnite ornament and double bird heads (Fig. 5, 5), written about by Ambroz ${ }^{30}$. Its dating was clarified by Furas'ev ${ }^{31}$ (2001) and Kazanskii ${ }^{32}$.

28 Dobrzańska $H$. Osada z późnego okresu rzymsiego w Igołomi, woj. krakowskie. Krakow, 1990.

29 The authors are grateful to A.M. Oblomskii for referring to the literary source.

${ }^{30}$ Ambroz A.K. Iuzhnye khudozhestvennye sviazi naseleniia Verkhnego Podneprov'ia v VI v. [Southern artistic ties of the of the Upper Dnieper population in the $6^{\text {th }}$ century] // Kukharenko Yu.V. (Ed.), Drevnie slavyane i ikh sosedi [Ancient Slavs and their neighbours]. Moskva, 1970. P. 73. (In Russ.)

31 Furas'ev A.G. O datirovke i proiskhozhdenii odnoi gruppy priazhek epokhi velikogo pereseleniia narodov [On the dating and origin of one group of buckles of the Great Migration period] // Soobshcheniya Gosudarstvennogo Ermitazha [Transactions of the State Hermitage Museum]. No. LIX. Sankt-Peterburg, 2001. P. 24-27. (In Russ.)

32 Kazanskii M.M. O baltakh v lesnoi zone Rossii v epo$\mathrm{khu}$ velikogo pereseleniia narodov [About the Balts in the forest zone of Russia in the Migration period] // Arkheologicheskie vesti [Archaeological news]. Issue 6. Sankt-Peterburg, 1999. P. 404-419. (In Russ.); Kazanskii M.M. Prestizhnye nakhodki i tsentry vlasti postgunskogo vremeni v Podneprov'e [Prestigious finds and post-Hunnic centres of power power in the Dnieper region] // Stratum plus. 2018. No. 4. P. 83-118. (In Russ.). Kazanskii gives a wider dating: the second half of the $5^{\text {th }}-$ the first half of the 6th century AD. 
Akhmedov identified the links between the eagleheaded buckle from Demidovka and items from Ryazan-Oka burial grounds ${ }^{33}$.

A series of radiocarbon dates obtained on samples taken from the excavations of the upper layer of Demidovka unambiguously points to the turn of the $5 / 6^{\text {th }}$ century with the greatest probability (Table 2). Based on the fact that there are no later finds, it can be assumed that life on the site has not been recommenced.

This era - the turn of the $5 / 6^{\text {th }}$ century - corresponds very well to the troubled time of deep transformations that covered a significant part of the forest zone of Eastern Europe, most likely caused by the general European restructuring after Attila's death and, as a consequence, the expansion into the forest zone of relatively few, but highly militarized groups of heterogeneous (Germanic? Hunnic? Slavic? Baltic?) origin. Archaeological data on the era of Migration period indicate a sharp increase in military danger in a significant part of the forest zone, from the Upper Volga Region to the Neman. Traces of fire and destruction were noted in a number of fortified settlements, and in a number of cases, for example, in Demidovka, Aukstadvaris, Aukuro-Kalnas, obvious traces of military action were revealed. It is indicative that in these three fortified settlements, "steppe" three-blade arrowheads, uncharacteristic for the forest zone, were found ${ }^{34}$. Such an arrow lodged in the bones of a man buried at the Plinkaigalis

\footnotetext{
33 Akhmedov I.R. Nekotorye indikatory kul'turnykh vzaimodeistvii v drevnostiakh riazano-okskikh finnov vtoroi poloviny V - nachala VI v. [Some indicators of cultural interactions in antiquities of the Ryazan-Oka Finns of the second half of the $5^{\text {th }}$-early $6^{\text {th }}$ century] $/ /$ Oblomskii A.M. (Ed.), Problemy vzaimodeistviia naseleniia Vostochnoi Evropy $\mathrm{v}$ epokhu Velikogo pereseleniia narodov [Issues of interaction between the population of Eastern Europe in the Migration Period]. Moskva, 2014. P. 138-177. (In Russ.)

34 The arrows found at the fortified settlement of Demidovka are divided into two chronological groups. The arrowheads of rhombic outlines, broadening in the middle part, Zasetskaya Type 1 (for example, Fig. 4, 13, 14, 17), are most characteristic of the Hunnic period. The arrowheads, broadening mostly to the stem, Zasetskaya Type 3 (Fig. 4, $9,10,16)$, were also used in the post-Hunnic time (Zasetskaia I.P. Kul'tura kochevnikov iuzhnorusskikh stepei v gunnskuiu epokhu (konets IV - V v.) [Culture of nomads of the southern Russian steppes in the Hun period (the late $4^{\text {th }}-5^{\text {th }}$ century)]. Sankt-Peterburg, 1994. P. 36-39 (In Russ.)). The late date of the latter type is determined, in particular, by the find in the Kerch crypt 152 of 1904, where these arrowheads were found with a Gepid buckle from the first half of the $6^{\text {th }}$ century (Kazanskii M.M. Vooruzhenie i konskoe snariazhenie slavian V-VII vv. [Armament and horse equipment of the Slavs of the $5^{\text {th }}-7^{\text {th }}$ centuries] $/ /$ Stratum plus. 2015. No. 5. P. 63. (In Russ.)).
}

burial ground. It would be wrong to associate these arrows only with steppe nomads; they were widely used by sedentary barbarians, in particular, by the Slavs and Germans. Three-bladed earlymedieval arrows are found even in Norway and Gotland $^{35}$, where the steppe inhabitants could not be at that time. It should be reminded that multiethnic barbarian military-political formations, such as the union of the Vandals, Suevi and Alans, the Goto-Hunno-Alan army of Alafei and Safrak, the kingdom of Odoacer in Italy, which included the Skirs, Torkilings, Rugs and Heruls, the Sklavino-Lombard army of Prince Ildiges, are rather characteristic of the era of Migration period. In these formations, the orientation towards a prestigious leader or dynasty played a much more important role than the ethnic origin of the warriors who made up a particular group ${ }^{36}$.

There are still more questions than answers in the interpretation of the fortified settlement of Vyazovenki. A bronze brooch rimmed with bird's heads was found in a small excavation in pre-continental stratum 5 close to virgin soil (Fig. 5, 21). This type of brooches is considered in detail by Rodinkova ${ }^{37}$ (Fig. 1, 37-40). According to this classification, the brooch from the fortified settlement of Vyazovenki relates to the sevenheaded subtype, series B, Voloshskoe variant, it is characterized by reduced lateral ledges. The variant within the type is relatively late, but the common date for all variants is the same - no later than the

35 Nørgård Jørgensen A. Waffen und Gräber. Typologische und chronologische Studien zu skandinavischen Waffengräbern 520/30 bis 900 n. Chr. København, 1999. P. 109. Abb. 96, 6; 97, 1.

${ }^{36}$ Kazanski M. La zone forestière de la Russie et l'Europe centrale à la fin de l'époque des Grandes Migrations // Mączyńska M., Grabarczyk T. (Eds.), Die spätrömische Kaiserzeit und die frühe Völkerwanderungszeit in Mittelund Osteuropa. Lódż, 2000. P. 406-459; Akhmedov I.R., Kazanskii M.M. Posle Attily. Kievskii klad i ego kul'turnoistoricheskii kontekst [After Attila. The Kiev hoard and its cultural and historical context] // Goryunova V.M., Shcheglova O.A. (Eds.), Kul'turnye transformatsii i vzaimovliianiia v Dneprovskom regione na iskhode rimskogo vremeni i v rannem Srednevekov'e [Cultural transformations and mutual influences in the Dnieper region at the end of Roman period and in the early Middle Ages]. SanktPeterburg, 2004. P. 168-202. (In Russ.)

37 Rodinkova V.E. Dneprovskie fibuly s kaimoi iz ptich'ikh golov [Dnieper fibulae with bird-head diadems] // Goryunova V.M., Shcheglova O.A. (Eds.), Kul'turnye transformatsii i vzaimovliianiia v Dneprovskom regione na iskhode rimskogo vremeni i v rannem Srednevekov'e [Cultural transformations and mutual influences in the Dnieper region at the end of the Roman period and in the early Middle Ages]. SanktPeterburg, 2004. P. 233-243. (In Russ.) 
middle of the $7^{\text {th }}$ century, which is determined by the date of the Antean first-group hoards according to Shcheglova ${ }^{38}$. Analogies have been identified on the island of Gotland, in Trubchevsk on the Desna, and in the Middle Dnieper. By the way, a series of Antean brooches, as well as a small "Danube" brooch of the $7^{\text {th }}$ century, often accompanying Antean antiquities, have also been found at the fortified settlement of Nikodimovo ${ }^{39}$ (Table 23, 3-8).

Attention is drawn to the correlation of figurative motifs of eagle heads, made in the "East German" manner ${ }^{40}$, on a buckle from Demidovka and a brooch from Vyazovenki. Two finds in the region, relating to successive periods, separated by an interval of at least 100 years, give a hint of the unity of the plot that was popular among the local population (possibly its elite part). According to the mapping by Rodinkova, although birdheaded brooches are part of a single adornment complex of the "Antean Union" (KolochinskPenkovsk community), however, the fashion for bird-headed fasteners spread only to a certain part of the Antean population living in the Middle Dnieper region ${ }^{41}$. After the find in Vyazovenki,

38 Shcheglova O.A. Svintsovo-oloviannye ukrasheniia VIII-X vv. na severo-zapade Vostochnoi Evropy [Leadtin ornaments of the $8^{\text {th }}-10^{\text {th }}$ centuries in the northwest of Eastern Europe] // Kirpichnikov A.N. (Ed.), Ladoga i ee sosedi $v$ epokhu srednevekov'ia [Ladoga and its neighbours in the Middle Ages]. Sankt-Peterburg, 2002. P. 134-150. (In Russ.). See the clarifications on the hoards burial time of this group: Kazanskii M.M. Arkheologicheskaia situatsiia v Srednem Podneprov'e v VII v. [Archaeological situation in the Middle Dnieper region in the $7^{\text {th }}$ century] // Oblomskii A.M. (Ed.), Problemy vzaimodeistviia naseleniia Vostochnoi Evropy $\mathrm{v}$ epokhu Velikogo pereseleniia narodov [Issues of interaction between the population of Eastern Europe in the Migration Period]. Moskva, 2014. P. 53-55. (In Russ.)

39 Schmidt E.A. Tushemlinskaia kul'tura [The Tushemlya culture]. Smolensk, 2003. (In Russ.)

40 Akhmedov I.R. Nekotorye indikatory kul'turnykh vzaimodeistvii $\mathrm{v}$ drevnostiakh riazano-okskikh finnov vtoroi poloviny V - nachala VI v. [Some indicators of cultural interactions in antiquities of the Ryazan-Oka Finns of the second half of the $5^{\text {th }}$-early $6^{\text {th }}$ century] $/ /$ Oblomskii A.M. (Ed.), Problemy vzaimodeistviia naseleniia Vostochnoi Evropy v epokhu Velikogo pereseleniia narodov [Issues of interaction between the population of Eastern Europe in the Migration Period]. Moskva, 2014. P. 149. (In Russ.)

${ }^{41}$ Rodinkova V.E. Dneprovskie fibuly s kaimoi iz ptich'ikh golov [Dnieper fibulae with bird-head diadems] // Goryunova V.M., Shcheglova O.A. (Eds.), Kul'turnye transformatsii i vzaimovliianiia $\mathrm{v}$ Dneprovskom regione na iskhode rimskogo vremeni i v rannem Srednevekov'e [Cultural transformations and mutual influences in the Dnieper region at the end of the Roman period and in the early Middle Ages]. Sankt-Peterburg, 2004. P. 238. (In Russ.) an eloquent point in the Smolensk Dnieper region is added to this area and the Trubchevsk hoard on the Desna. It is possible that the bearers of this tradition were not the Antes, but some other ethnic component, the origin of which has yet to be clarified. Thus, it is appropriate to refer to the hypothesis of Akhmedov on the participation of the Upper Dnieper school (according to Ambroz), which has Danube East German roots in the second half of the $5^{\text {th }}$ century, in the formation of the jewelry art of the Middle Dnieper region in the $6^{\text {th }}-$ first half of the $7^{\text {th }}$ century ${ }^{42}$.

At the fortified settlement of Vyazovenki, when clearing a wartime trench, Shmidt ${ }^{43}$ (Photo 33, 1) found a fragment of a silver neck-ring (Fig. 5, 2), similar in shape to bronze neck-rings from a hoard of the $7^{\text {th }}$ century (?) from the fortified settlement of Vezhki in Belarus ${ }^{44}$ (Fig. 2).

Neck-rings with such lock is well known in the Balt early-medieval context. In particular, there are many of them in the territory of historical villages $^{45}$, in the basin of the Western Dvina ${ }^{46}$, but they are also found in other Baltic territories. Some of these neck-rings have a wire winding,

42 Akhmedov I.R. Nekotorye indikatory kul'turnykh vzaimodeistvii v drevnostiakh riazano-okskikh finnov vtoroi poloviny $\mathrm{V}$ - nachala VI v. [Some indicators of cultural interactions in antiquities of the Ryazan-Oka Finns of the second half of the $5^{\text {th }}$-early $6^{\text {th }}$ century] $/ /$ Oblomskii A.M. (Ed.), Problemy vzaimodeistviia naseleniia Vostochnoi Evropy v epokhu Velikogo pereseleniia narodov [Issues of interaction between the population of Eastern Europe in the Migration Period]. Moskva, 2014. P. 156. (In Russ.)

43 Schmidt E.A. Otchet o raskopkakh i razvedkakh na territorii Smolenskoi oblasti v 1972 g. [Report on excavations and surveys in the territory of the Smolensk Region in 1972] // Arkhiv Instituta arkheologii Rossiyskoy akademii nauk [Archive of the Institute of Archaeology RAS]. 1972. R-1, No. 4840. (In Russ.)

44 Kolosovskii Yu.V. Gorodishche i selishche okolo derevni Vezhki Dubrovenskogo raiona Vitebskoi oblasti. Issledovaniia 1994-1998 gg. [A fortified settlement and a settlement near the village of Vezhki, Dubrovno district of Vitebsk Region. Research of 1994-1998] // Slaviane na territorii Belarusi $v$ dogosudarstvennyi period [Slavs in the territory of Belarus in the pre-state period]. Book 1. Minsk, 2019. P. 336-344. (In Russ.)

45 The Selonians is a Baltic people who lived until the $15^{\text {th }}$ century in Selonia in the south-east of modernday Latvia, as well as in the north-east of modern-day Lithuania. They spoke the Selonian language of the Baltic group and were part of the Latvians and Lithuanians. Mentioned since the $2^{\text {nd }}$ century.

46 See, for example: Giriciuviene E. Sèliai. The Selonians. Vilinius; Riga, 2007. 
like a neck-ring Vyazovenki ${ }^{47}$. In the area of the Selonians, neck-rings with such lock date back to the E3 period, i.e. $600-650 / 680^{48}$, although in general their period of existence was apparently somewhat wider. For example, this can be evidenced by the fact that late forms of neckrings with a saddle-shaped lock were found in the hoards of the $9^{\text {th }}$ century in Ivakhniki, Uzmino, Gorki $^{49}$ (Table I, 4; III, 1-3; IV).

Thus, based on the discovery of two outstanding things against the background of an insignificant amount of field work, it can be assumed that the fortified settlement of Vyazovenki became a local center instead of the fortified settlement of Demidovka, in order to then pass it on to Smolensk (Cathedral Hill) and Gnezdovo.

What is a cultural attribution of the upper layers of fortified settlements of Demidovka and Vyazovenki? They appear in literature along with Tushemlin and Kolochin ones. The similarity of ceramics of the fortified settlement of Demidovka with the materials of excavations of the eponymous fortified settlement of Kolochin $1^{50}$ was established long ago: this was written about by $\mathrm{Schmidt}^{51}$ in a field report, then by Tret'iakov ${ }^{52}$ and Lopatin ${ }^{53}$.

${ }^{47}$ See, for example: Urtans $V$. Senākie depozīti Latvija (līidz 1200 g.). Riga, 1977. Att. 66.4; Tautavičius A. Vidurinis geležies amžius Lietuvoje (V-IX a.). Vilnius, 1996. P. 76. 2 pav; Carnap-Bornheim, C. von, Hilberg, F., Radinšs, A., Schopper, F. (Eds.). Lettlands viele Völker. Archäologie der Eisenzeit von Christi Geburt bis zum Jahr 1200. Brandenburg - Schleswig. Archäologischens Landesmuseum im Paulkloster, Archäologisches Landesmuseum. Gottorf, 2009. P. 110. No. 26.

48 Bliujienè A. Roėniškasis ir tautų kraustymosi laikotarpiai. Klaipėda, 2013. 365 pav.

${ }^{49}$ Korzukhina G.F. Russkie klady IX-XIII vv. [Hoards of the $9^{\text {th }}-13^{\text {th }}$ century Rus]. Moscow; Leningrad, 1954. (In Russ.)

50 Symonovich E.A. Gorodishche Kolochin 1 na Gomel'shchine [The Kolochin 1 settlement in the Gomel region] // Rybakov B.A. (Ed.), Slaviane nakanune obrazovaniia Kievskoi Rusi [Slavs on the eve of the formation of Kievan Rus]. Moskva, 1963. P. 97-137. (In Russ.)

${ }^{51}$ Schmidt E.A. Otchet o raskopkakh i razvedkakh na territorii Smolenskoi oblasti v $1972 \mathrm{~g}$. [Report on excavations and surveys in the territory of the Smolensk Region in 1972] // Arkhiv Instituta arkheologii Rossiyskoy akademii nauk [Archive of the Institute of Archaeology RAS]. 1972. R-1, No. 4840.

52 Tret'iakov P.N. Po sledam drevnikh slavianskikh plemen [In the footsteps of ancient Slavic tribes]. Leningrad, 1982 P. 71. (In Russ.)

53 Lopatin N.V. Tushemlia, Demidovka, Kolochin. O sootnoshenii keramiki verkhnikh sloev [Tushemlya, Demidovka, Kolochin. The correlations of pottery from the upper layers] // Kratkie soobshcheniia Instituta arkheologii [Brief Communications of the Institute of Archaeology]. 1989. Issue 195. P. 9-15. (In Russ.)
However, the unification into one archaeological culture of such heterogeneous sites as the fortified settlements of the Upper Dnieper of the Smolensk land and Belarus and open settlements of more southern regions (the Seim and Psla basins) raises questions. Ceramic traditions are similar in general terms, but it is likely that a full-scale comparison, which has not yet been carried out, will reveal separate variants. Differences in other features (the nature of the sites, house-building) are even more noticeable. There are even fewer reasons to consider the fortified settlement of Demidovka as Tushemlin - there are too many differences between the fortified settlements of Demidovka and Tushemlya.

In the materials of the fortified settlement of Demidovka, there is a clear overlapping (and mixing?) of different ethnic, more precisely cultural, traditions, presumably Slavic and Germanic ones. The first ones include ceramics, which find parallels in the Kiev and Kolochin cultures, the latter include a Chernyakhov goblet and an eagle-headed buckle. However, ethnic interpretation is almost always ambiguous. It should be emphasized that a complex social hierarchy is reliably shown by the remnants of material culture. In the fortified settlement of Demidovka, the features of the regional "power center" are clearly visible, distinguishing it from other fortified settlements. Finds from the fortified settlement of Vyazovenki suggest that in the $7^{\text {th }}$ century, near Smolensk there was a local "power center". The geography of the found birdheaded brooches show that in the $7^{\text {th }}$ century, there were contacts connecting the Smolensk land, the Middle Dnieper, and Gotland. It is appropriate to mention "Gutasaga" about the contacts of Gotland with Eastern Europe along the Western Dvina ${ }^{54}$.

The finds described in the article allow taking a completely different look at the credibility of Scandinavian sagas "about ancient times" with their mention of the country "Gardariki", "Kings of Gardariki". Also, the finds of the middle of the $1^{\text {st }}$ millennium AD in the Dnieper floodplain near Gnezdovo are viewed in a different way in the context of the finds from Demidovka and

\footnotetext{
${ }^{54}$ Kovalevskii S.D. "Saga o gutakh" (perevod i kommentarii) ["The Gutasaga" (translation and commentary)] // Srednie veka [Middle Ages]. Issue 38. Moskva, 1975. P. 307-311. (In Russ.)
} 
Vyazovenki ${ }^{55}$. An urgent task for future research is to find out where the power/settlement centers were located in the Smolensk Region during the entire second half of the $1^{\text {st }}$ millennium AD.

The authors express their gratitude to O.V. Sharov for consultations, as well as to the staff of the Archeology Department of the Smolensk Museum, where the collections are kept.

The article was prepared with the financial support of the Russian Foundation for Basic Research within the framework of Research Project No. 20-09-00171.

\section{REFERENCES}

Akhmedov I.R. Nekotorye indikatory kul'turnykh vzaimodeistvii $\mathrm{v}$ drevnostiakh riazano-okskikh finnov vtoroi poloviny V - nachala VI v. [Some indicators of cultural interactions in antiquities of the Ryazan-Oka Finns of the second half of the $5^{\text {th }}$-early $6^{\text {th }}$ century] $/ /$ Oblomskii A.M. (Ed.), Problemy vzaimodeistviia naseleniia Vostochnoi Evropy v epokhu Velikogo pereseleniia narodov [Issues of interaction between the population of Eastern Europe in the Migration Period]. Moskva, 2014. P. 138-177. (In Russ.)

Akhmedov I.R., Kazanskii M.M. Posle Attily. Kievskii klad i ego kul'turno-istoricheskii kontekst [After Attila. The Kiev hoard and its cultural and historical context] // Goryunova V.M., Shcheglova O.A. (Eds.), Kul'turnye transformatsii i vzaimovliianiia v Dneprovskom regione na iskhode rimskogo vremeni i v rannem Srednevekov'e [Cultural transformations and mutual influences in the Dnieper region at the end of Roman period and in the early Middle Ages]. Sankt-Peterburg, 2004. P. 168-202. (In Russ.)

Ambroz A.K. Iuzhnye khudozhestvennye sviazi naseleniia Verkhnego Podneprov'ia v VI v. [Southern artistic ties of the of the Upper Dnieper population in the $6^{\text {th }}$ century] // Kukharenko Yu.V. (Ed.), Drevnie slavyane i ikh sosedi [Ancient Slavs and their neighbours]. Moskva, 1970. P. 70-74. (In Russ.)

Drobushevskii A. Etnokul'turnye izmeneniia v mezhdurech'e Dnepra i Desny na rubezhe nashei ery [Ethnic and cultural changes in the interfluve of the Dnieper

55 Zakharov E.V. Follis Litsiniia I (308-324) iz Gnezdova [A follis of Licinius I (308-324) from Gnezdovo] // Gnezdovskiy arkheologicheskiy kompleks [The Gnezdovo archaeological complex]. Moscow, 2018. P. 179-180 (In Russ.); Shevtsov A.O. Kollektsii vizantiiskikh monet Gnezdova i Kieva v kontekste kontaktov Rusi i Vizantii v IX-XI vv. [Collections of Byzantine coins from Gnezdovo and Kiev in the context of contacts between Rus and Byzantium in the 9th-11th centuries] // Gnezdovskii arkheologicheskii kompleks [The Gnezdovo archaeological complex]. Moskva, 2018. (In Russ.) and Desna at the dawn of the Common era] // Gistarychna-arkhealagichny zbornik [Historical and archaeological collection of papers]. No. 26. Minsk, 2011. P. 76-83. (In Russ.)

Ershova E.G., Bakumenko V.O., Vorontsov T.P., Goncharov M.M., Klimenko M.S., Kulikov N., Revokatova D.P., Selezneva E.M., Farish N.R., Fetisova E.S., Yakovenko E.P. Sporovo-pyl'tsevye spektry sovremennogo i srednevekovogo konskogo navoza [Spore-pollen spectra of modern and medieval manure dung] // Paleopochvy, paleoekologiia, paleoekonomika [Palaeosoils, palaeoecology, palaeoeconomics]. Pushchino, 2017. P. 70-74. (In Russ.)

Furas'ev A.G. Demidovka i Uzmen'. "Netraditsionnyi vzgliad" na "klassicheskie" pamiatniki [Demidovka and Uzmen. "An unconventional view" of the "classical" sites] // Belarus' u sisteme ey̆rapeyskikh kul'turnykh suvyazyay̆ [Belarus in the framework of European cultural ties]. Minsk, 1997. P. 33-38. (In Russ.)

Furas'ev A.G. O datirovke i proiskhozhdenii odnoi gruppy priazhek epokhi velikogo pereseleniia narodov [On the dating and origin of one group of buckles of the Great Migration period] // Soobshcheniya Gosudarstvennogo Ermitazha [Transactions of the State Hermitage Museum]. No. LIX. SanktPeterburg, 2001. P. 24-27. (In Russ.)

Kazanskii M.M. O baltakh v lesnoi zone Rossii v epokhu velikogo pereseleniia narodov [About the Balts in the forest zone of Russia in the Migration period] // Arkheologicheskie vesti [Archaeological news]. Issue 6. Sankt-Peterburg, 1999. P. 404-419. (In Russ.)

Kazanskii M.M. Arkheologicheskaia situatsiia v Srednem Podneprov'e v VII v. [Archaeological situation in the Middle Dnieper region in the $7^{\text {th }}$ century] // Oblomskii A. M. (Ed.), Problemy vzaimodeistviia naseleniia Vostochnoi Evropy v epokhu Velikogo pereseleniia narodov [Issues of interaction between the population of Eastern Europe in the Migration Period]. Moskva, 2014. P. 45-137. (In Russ.)

Kazanskii M.M. Vooruzhenie i konskoe snariazhenie slavian V-VII vv. [Armament and horse equipment of the Slavs of the $5^{\text {th }}-7^{\text {th }}$ centuries] $/ /$ Stratum plus. 2015. No. 5. P. 43-95. (In Russ.)

Kazanskii M.M. Prestizhnye nakhodki i tsentry vlasti postgunskogo vremeni v Podneprov'e [Prestigious finds and post-Hunnic centres of power power in the Dnieper region] // Stratum plus. 2018. No. 4. P. 83-118. (In Russ.)

Kazanskii M.M. O voennoi organizatsii slavian v VVII vekakh: vozhdi, professional'nye voiny i arkheologicheskie dannye [On the military organization of the Slavs in the $5^{\text {th }}-7^{\text {th }}$ centuries: leaders, professional warriors and archaeological data] // Stratum plus. 2019. No. 5. P. 15-28. (In Russ.) 
Kazanskii M.M. O poiasakh s nakladnymi uzkimi plastinami iz mogil'nika Luchistoe [Belts with applied narrow plaques from the Luchistoye cemetery] // Khairedinova E.A. (Ed.), Problemy istorii i arkheologii srednevekovogo Kryma: materialy mezhdunar. konf., posviashch. 70-letiiu A.I. Aibabina [Aspects of the history and archaeology of medieval Crimea: Proceedings of the International Conference to the $70^{\text {th }}$ Anniversary of A.I. Aybabin]. Simferopol, 2019. P. 60-64. (In Russ.)

Kolosovskii Yu.V. Gorodishche i selishche okolo derevni Vezhki Dubrovenskogo raiona Vitebskoi oblasti. Issledovaniia 1994-1998 gg. [A fortified settlement and a settlement near the village of Vezhki, Dubrovno district of Vitebsk Region. Research of 1994-1998] // Slaviane na territorii Belarusi $\mathrm{v}$ dogosudarstvennyi period [Slavs in the territory of Belarus in the pre-state period]. Book 1. Minsk, 2019. P. 336-344. (In Russ.)

Korzukhina G.F. Russkie klady IX-XIII vv. [Hoards of the $9^{\text {th }}-13^{\text {th }}$ century Rus]. Moscow; Leningrad, 1954. (In Russ.)

Kovalevskii S.D. "Saga o gutakh" (perevod i kommentarii) ["The Gutasaga" (translation and commentary)] // Srednie veka [Middle Ages]. Issue 38. Moskva, 1975. P. 307-311. (In Russ.)

Krasnov Yu.A. (Ed.). Arkheologicheskaia karta Rossii. Smolenskaia oblast' [Archaeological map of Russia. Smolensk Region]. Moskva, 1997. (In Russ.)

Levko O.N., Kolosovskii Yu.V. Raskopki gorodishch u d. Kiseli (Dymokury) Tolochinskogo raiona i u d. Cherkasovo Orshanskogo raiona Vitebskoi oblasti [Excavations of fortified settlements near the village of Kiseli (Dymokury), Tolochin district, and the village of Cherkasovo, Orsha district of Vitebsk Region] // Rannie slaviane Belorusskogo Podneprov'ia i Podvin'ia [Early Slavs of Belarusian area of the Dnieper and Dvina river regions]. Minsk, 2003. P. 182-208. (In Russ.)

Lopatin N.V. Tushemlia, Demidovka, Kolochin. O sootnoshenii keramiki verkhnikh sloev [Tushemlya, Demidovka, Kolochin. The correlations of pottery from the upper layers] // Kratkie soobshcheniia Instituta arkheologii [Brief Communications of the Institute of Archaeology]. 1989. Issue 195. P. 9-15. (In Russ.)

Lopatin N.V. The Tushemlya and Kolochin cultures // Rodinkova V.E., Rumyantseva O.S. (Eds.), Evropa ot Latena do Srednevekov'ya: varvarskiy mir i rozhdenie slavyanskikh kul'tur: K 60-letiyu A.M. Oblomskogo [Europe from La Tune to the Middle Ages: the barbaric world and the birth of Slavic cultures: To the $60^{\text {th }}$ anniversary of A.M. Oblomsky]. Moskva, 2017. P. 63-69. (In Russ.)

Liavdanskii A.N., 1924. Materialy dlia arkheologicheskoi karty Smolenskoi gubernii [Materials for the archaeological map of Smolensk Province] // Trudy smolenskikh gosudarstvennykh muzeev [Research works of Smolensk state museums]. Issue 1. Smolensk, 1924. P. 127-184. (In Russ.)

Marzaliuk I. Novyia krynitsy pa gistoryi slavianskaga rassialennia y̆ magiley̆skim Padniproy̆i i Pasozhzhy [New sources on the history of Slavic settlement in Mogilev area of the Dnieper and Posozh River regions] // Gistarychna-arkhealagichny zbornik [Historical and archaeological collection of papers]. No. 26. Minsk, 2011. P. 97-118. (In Belarussian)

Miatsel'ski A.A. Staraday̆ni Krychay̆ [Old Krychau]. Minsk, 2003. (In Belarussian)

Nikitina G.F. Mogil'nik us. Oselivka Kel'menetskogo r-na Chernovitskoi obl. [A cemetery near the village of Oselivka, Kelmenetsi district of Chernivtsi Region] // Kropotkin V.V. (Ed.), Mogil'niki cherniakhovskoi kul'tury [Cemeteries of the Chernyakhov culture]. Moskva, 1988. P. 5-97. (In Russ.)

Oblomskii A.M. Kolochinskaia kul'tura [The Kolochin culture] // Oblomskii A.M., Islanova I.V. (Eds.), Rannesrednevekovye drevnosti lesnoi zony Vostochnoi Evropy V-VII vv. [Early medieval antiquities from the forest zone of Eastern Europe of the $5^{\text {th }}-7^{\text {th }}$ centuries]. Moskva, 2016. P. 10-113. (In Russ.)

Radiush O.A., Shcheglova O.A. Volnikovskii klad 1-i poloviny V v. v kontekste sinkhronnykh drevnostei epokhi Velikogo pereseleniia narodov [The Volnikovka hoard of the first half of the $5^{\text {th }}$ century in the context of synchronous antiquities of the Migration period] // Volnikovskii "klad" [The Volnikovka "hoard"]. Moskva, 2014. P. 4-25. (In Russ.)

Rodinkova V.E. Dneprovskie fibuly s kaimoi iz ptich'ikh golov [Dnieper fibulae with bird-head diadems] // Goryunova V.M., Shcheglova O.A. (Eds.), Kul'turnye transformatsii i vzaimovliianiia $v$ Dneprovskom regione na iskhode rimskogo vremeni $\mathrm{i} v$ rannem Srednevekov'e [Cultural transformations and mutual influences in the Dnieper region at the end of the Roman period and in the early Middle Ages]. SanktPeterburg, 2004. P. 233-243. (In Russ.)

Romanova G.A. Vily Iarugskie - mogil'nik IV v. n.e. [Vily Yarugskiye, a cemetery of the $4^{\text {th }}$ century AD] // Kropotkin V.V. (Ed.), Mogil'niki chernyakhovskoy kul'tury [Cemeteries of the Chernyakhov culture]. Moskva, 1988. P. 133-141. (In Russ.)

Sedin A.A. Predmety vooruzheniia, snariazheniia vsadnika i verkhovogo konia iz gorodishcha Nikodimovo [Weaponry, horseman and horse gear from the fortified settlement of Nikodimovo]. Mogilev, 2012. (In Russ.)

Sedov V.V. Gorodishche Tserkovishche [The fortified settlement of Tserkovishche] // Kratkie soobshcheniia Instituta arkheologii [Brief Communications of the Institute of Archaeology]. 1964. Issue 102. P. 70-74. (In Russ.) 
Sharov O.V. Khronologiia mogil'nikov Ruzhichanka, Kosanovo, Dancheny i problema datirovki cherniakhovskoi keramiki [Chronology of the Ruzhichanka, Kosanovo, and Dancheny cemeteries and the problem of Chernyakhov pottery dating] // Shchukin M.B., Gey O.A. (Eds.), Problemy khronologii epokhi latena i rimskogo vremeni [Issues of chronology of La Tène and the Roman period]. Sankt-Peterburg, 1992. P. 158-207. (In Russ.)

Shcheglova O.A. Svintsovo-oloviannye ukrasheniia VIII-X vv. na severo-zapade Vostochnoi Evropy [Lead-tin ornaments of the $8^{\text {th }}-10^{\text {th }}$ centuries in the northwest of Eastern Europe] // Kirpichnikov A.N. (Ed.), Ladoga i ee sosedi v epokhu srednevekov'ia [Ladoga and its neighbours in the Middle Ages]. Sankt-Peterburg, 2002. P. 134-150. (In Russ.)

Shevtsov A.O. Kollektsii vizantiiskikh monet Gnezdova i Kieva v kontekste kontaktov Rusi i Vizantii v IXXI vv. [Collections of Byzantine coins from Gnezdovo and $\mathrm{Kiev}$ in the context of contacts between Rus and Byzantium in the $9^{\text {th }}-11^{\text {th }}$ centuries] // Gnezdovskii arkheologicheskii kompleks [The Gnezdovo archaeological complex]. Moskva, 2018. (In Russ.)

Schmidt E.A. Otchet o raskopkakh i razvedkakh na territorii Smolenskoi oblasti v 1972 g. [Report on excavations and surveys in the territory of the Smolensk Region in 1972] // Arkhiv Instituta arkheologii Rossiyskoy akademii nauk [Archive of the Institute of Archaeology RAS]. 1972. R-1, No. 4840. (In Russ.)

Schmidt E.A. Nekotorye arkheologicheskie pamiatniki Smolenshchiny vtoroi poloviny I tys. n.e. [Some archaeological sites of the Smolensk land of the second half of the $1^{\text {st }}$ millennium AD] // Rybakov B.A. (Ed.), Slaviane nakanune obrazovaniia Kievskoi Rusi [Slavs on the eve of the formation of Kievan Rus]. Moskva, 1963. P. 51-67. (In Russ.)

Schmidt E.A. O kul'ture gorodishch-ubezhishch levoberezhnoi Smolenshchiny [About the culture of refuge fortified settlements in the left-bank Smolensk land] // Kukharenko Yu.V. (Ed.), Drevnie slaviane i ikh sosedi [Ancient Slavs and their neighbours]. Moskva, 1970. P. 63-69. (In Russ.)

Schmidt E.A. Arkheologicheskie pamiatniki Smolenskoi oblasti (s drevneishikh vremen do VIII v. n.e.) [Archaeological sites of Smolensk Region (from the earliest times to the $8^{\text {th }}$ century AD)]. Smolensk, 1976. (In Russ.)

Schmidt E.A. Plemena verkhov'ev Dnepra do obrazovaniia drevnerusskogo gosudarstva [Tribes of the upper Dnieper region before the formation of the Rus state]. Moskva, 1992. (In Russ.)

Schmidt E.A. Tushemlinskaia kul'tura [The Tushemlya culture]. Smolensk, 2003. (In Russ.)

Symonovich E.A. Gorodishche Kolochin 1 na Gomel'shchine [The Kolochin 1 settlement in the Gomel region] // Rybakov B.A. (Ed.), Slaviane nakanune obrazovaniia Kievskoi Rusi [Slavs on the eve of the formation of Kievan Rus]. Moskva, 1963. P. 97-137. (In Russ.)

Symonovich E.A. Pridunaiskii mogil'nik Furmanovka [The Danube cemetery of Furmanovka] // Kropotkin V.V. (Ed.), Mogil'niki cherniakhovskoi kul'tury [Cemeteries of the Chernyakhov culture]. Moskva, 1988. P. 164-167. (In Russ.)

Tret'iakov P.N. Po sledam drevnikh slavianskikh plemen [In the footsteps of ancient Slavic tribes]. Leningrad, 1982. (In Russ.)

Zakharov E.V. Follis Litsiniia I (308-324) iz Gnezdova [A follis of Licinius I (308-324) from Gnezdovo] // Gnezdovskiy arkheologicheskiy kompleks [The Gnezdovo archaeological complex]. Moscow, 2018. P. 179-180. (In Russ.)

Zasetskaia I.P. Kul'tura kochevnikov iuzhnorusskikh stepei v gunnskuiu epokhu (konets IV - V v.) [Culture of nomads of the southern Russian steppes in the Hun period (the late $4^{\text {th }}-5^{\text {th }}$ century)]. SanktPeterburg, 1994. (In Russ.)

Bliujiene A. Roėniškasis ir tautų kraustymosi laikotarpiai. Klaipeda, 2013.

Carnap-Bornheim, C. von, Hilberg, F., Radinš, A., Schopper, F. (Eds.). Lettlands viele Völker. Archäologie der Eisenzeit von Christi Geburt bis zum Jahr 1200. Brandenburg - Schleswig. Archäologischens Landesmuseum im Paulkloster, Archäologisches Landesmuseum.. Gottorf, 2009.

Dobrzańska $H$. Osada z późnego okresu rzymsiego w Igołomi, woj. krakowskie. Krakow, 1990.

Giriciuviene E. Sèliai. The Selonians. Vilinius; Riga, 2007.

Kazanski M. La zone forestière de la Russie et l'Europe centrale à la fin de l'époque des Grandes Migrations // Mączyńska M., Grabarczyk T. (Eds.), Die spätrömische Kaiserzeit und die frühe Völkerwanderungszeit in Mittel- und Osteuropa. Lódż, 2000. P. 406-459.

Maczyńska M., Urbaniak A., Jakubczyk I. The early medieval cemetery of Almalyk-dere near the foot of Mangup. Inter Ambo Maria. Contacts between Scandinavia and the Crimea in the Roman Period. Kristiansand; Simferopol, 2011. P. 154-175.

Nørgerd Jørgensen A. Waffen und Gräber. Typologische und chronologische Studien zu skandinavischen Waffengräbern 520/30 bis 900 n. Chr. København, 1999.

Nüsse H.-J. Haus, Gehöft und Siedlung im Norden und Westen der Germania magna. Rahden, 2014.

Tautavičius A. Vidurinis geležies amžius Lietuvoje (VIX a.). Vilnius, 1996.

Urtans V. Senākie depozīti Latvija (līdz 1200 g.). Riga, 1977. 